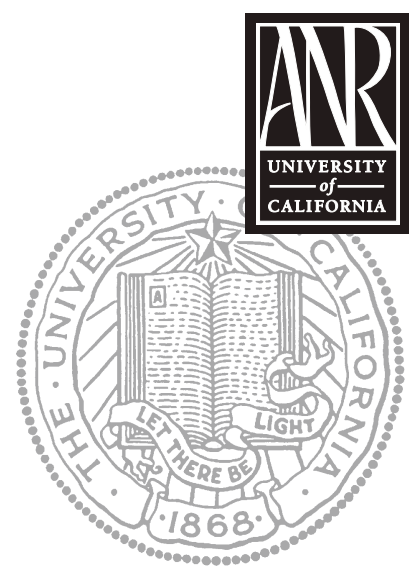

UNIVERSITY OF CALIFORNIA

Division of Agriculture and Natural Resources http://anrcatalog.ucdavis.edu In partnership with

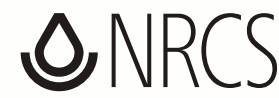

Natural

Resources Conservation Service

http://www.nrcs.usda.gov

Farm Water Quality Planning

A Water Quality and Technical Assistance Program for California Agriculture http://waterquality.ucanr.org

This PLAN is part of the Farm Water Quality Planning (FWQP) series, developed for a short course that provides training for growers of irrigated crops who are interested in implementing water quality protection practices. The short course teaches the basic concepts of watersheds, nonpoint source pollution (NPS), siteassessment techniques, and evaluation techniques. Management goals and practices are presented for a variety of cropping systems.
PUBLICATION 8332

\section{The Farm Water Quality Plan}

Plan components compiled by MARY BIANCHI, UC Cooperative Extension Farm Advisor, San Luis Obispo County; DANIEL MOUNTJOY, Area Resource Conservationist, USDA-NRCS; and ALISON JONES, Watershed Management Initiative Coordinator, Central Coast Regional Quality Control Board.

Use these sections to formalize a Farm Water Quality Plan for your farm.

This is the Farm Water Quality Plan for

Prepared by:

Date:

\section{CONTENTS}

Section

page

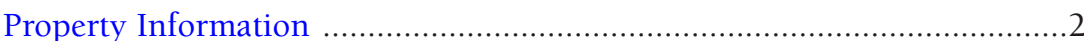

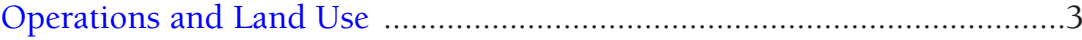

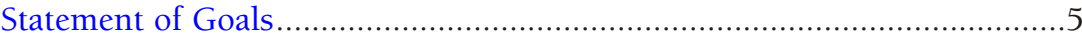

Regional and Local Water Quality Information ..........................................

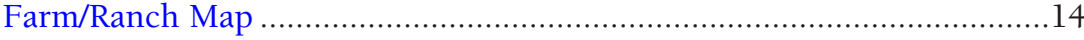

Site Assessment and Practices Planning ......................................... 12

Managing Sediment

Practices to Improve Water Quality in Waterways ..................... 39

Self-Evaluation 44 


\section{PROPERTY INFORMATION}

\section{Farm/Ranch}

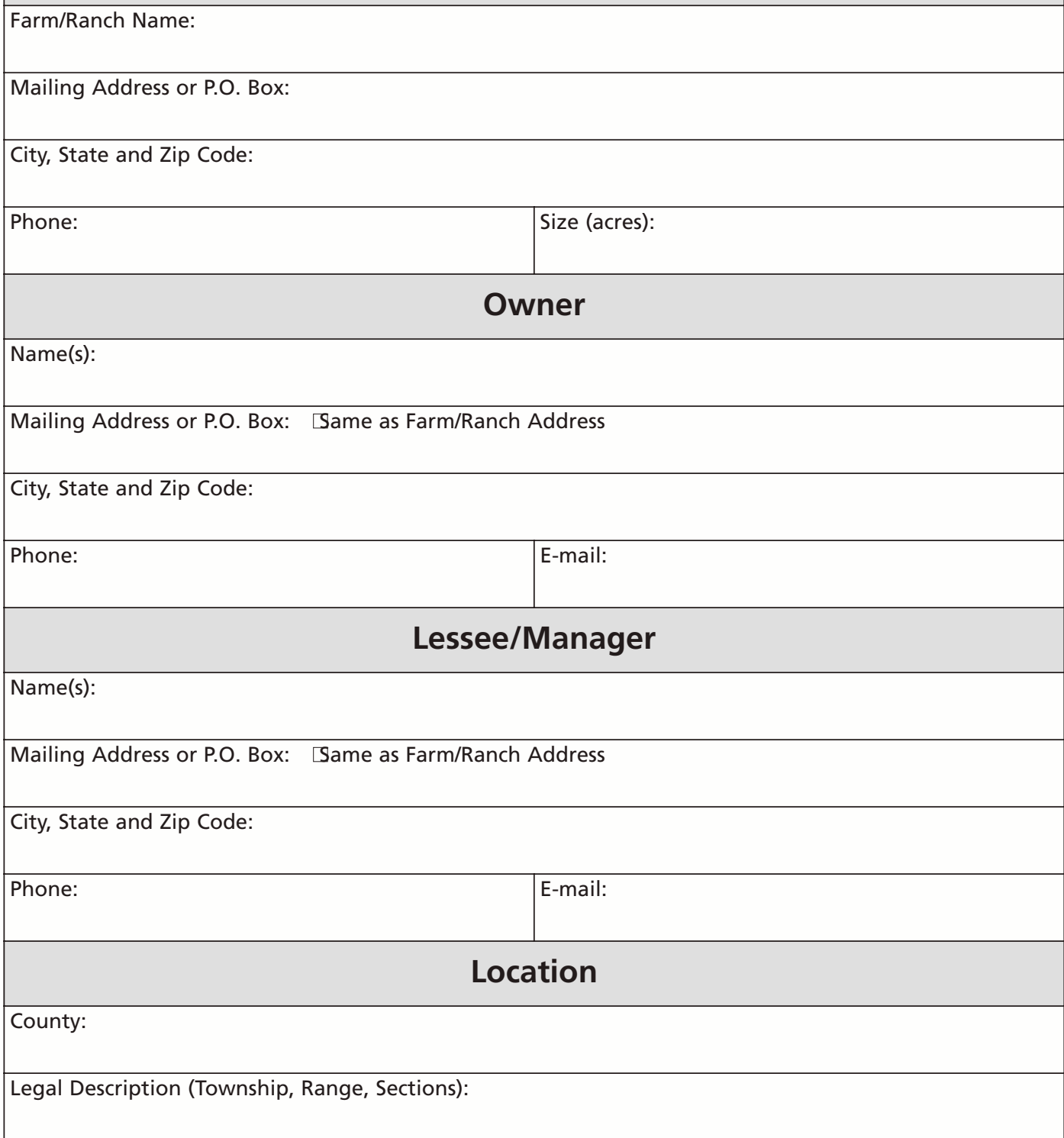




\section{OPERATIONS AND LAND USE}

\section{Current farm/ranch enterprises or activities} and the acreage devoted to each

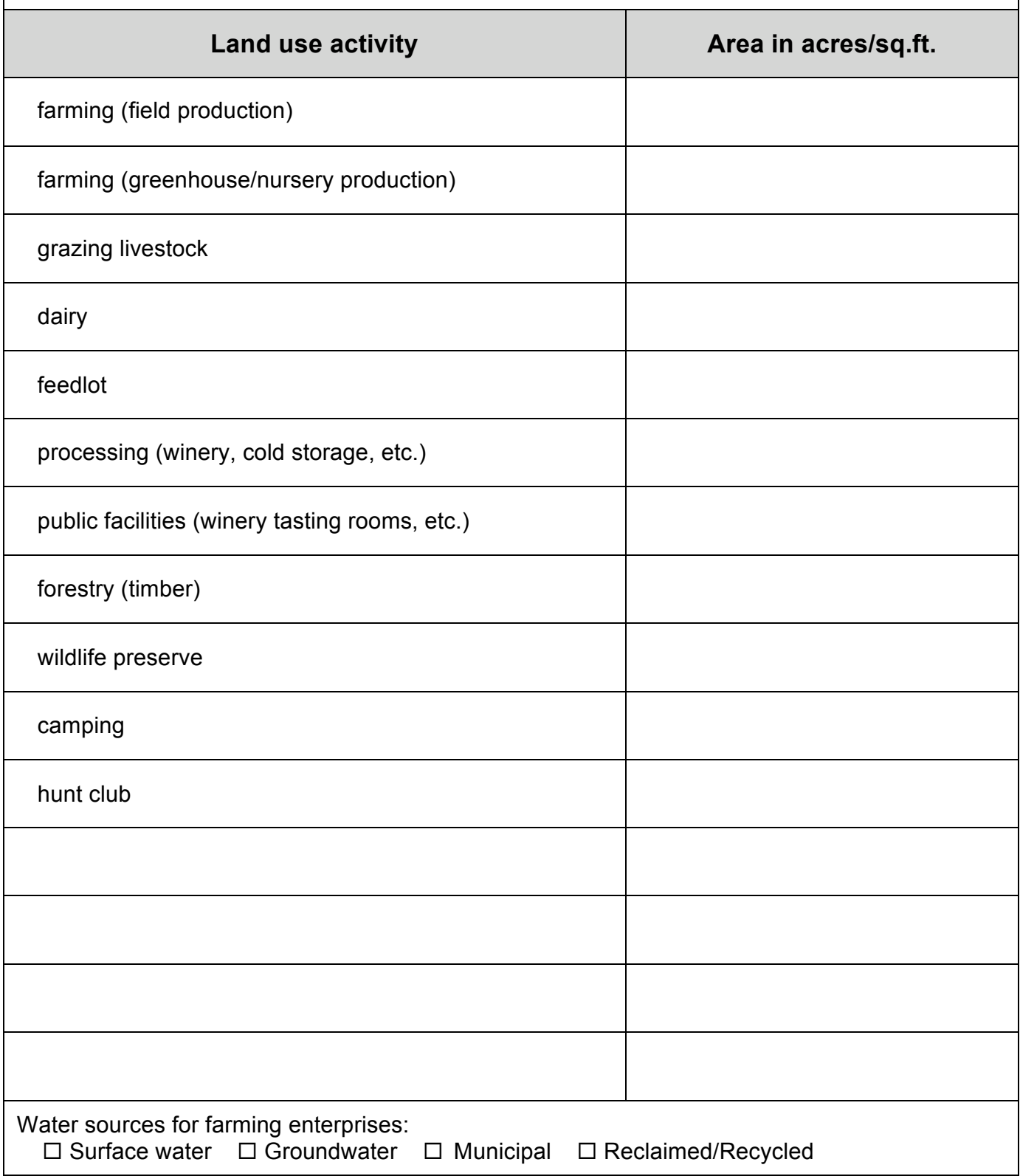


Operations and Land use, cont'd.

\section{Farming Enterprises}

\section{Current farm/ranch enterprises or activities and the acreage devoted to each}

\begin{tabular}{|c|c|c|}
\hline$\square$ Alfalfa/other hay & $\square$ Cotton & $\square$ Strawberries \\
\hline$\square$ Caneberries & $\square$ Field crops & $\square$ Tree/fruit/nut crops \\
\hline$\square$ Corn (grain) & $\square$ Irrigated pasture & $\square$ Vegetable crops \\
\hline$\square$ Corn (silage) & $\square$ Oil crops & $\square$ Vineyard \\
\hline$\square$ Other silage & $\square$ Rice & $\square$ Wheat, barley, oats \\
\hline $\begin{array}{c}\square \text { Greenhouse } \\
\square \text { Container } \\
\square \text { Ground }\end{array}$ & $\begin{array}{l}\square \text { Shade \& temporary } \\
\square \text { Container } \\
\square \text { Ground }\end{array}$ & $\begin{array}{l}\square \text { Outdoor flowers } \\
\square \text { Container } \\
\square \text { Ground }\end{array}$ \\
\hline$\square$ & $\square$ & $\square$ \\
\hline$\square$ & $\square$ & $\square$ \\
\hline
\end{tabular}

Schedule for rotated crops:

\section{Livestock Enterprises}

Number of pastures for grazing

\begin{tabular}{|l|l|}
\multicolumn{1}{|c|}{ Types of livestock } & \multicolumn{1}{c|}{ Livestock access to water } \\
\hline$\square$ cow/calf-spring calving & $\square$ troughs and tanks \\
\hline$\square$ cow/calf-fall calving & $\square$ springs \\
\hline$\square$ cow/calf-year-round calving & $\square$ streams or creeks \\
\hline$\square$ stocker production & $\square$ stock ponds \\
\hline$\square$ goat production & $\square$ water gaps \\
\hline$\square$ llama production & $\square$ wells \\
\hline$\square$ horses & $\square$ river \\
\hline$\square$ ratite (ostrich, emu, etc.) production & $\square$ \\
\hline$\square$ & $\square$ \\
\hline$\square$ & $\square$ \\
\hline
\end{tabular}




\section{STATEMENT OF GOALS}

\section{Production Goals}

$\square$ to pass the farm/ranch on to the next generation

$\square$ to reduce family/farm debt so that only minor borrowing for operating capital is necessary in a typical year

$\square$ to expand existing enterprises

$\square$ to increase income by developing new enterprises

$\square$ to increase profitability

$\square$ to purchase or lease more property

$\square$ to reduce short-term production costs

$\square$ to achieve long-term reduced production costs

$\square$ to increase the value of the land

$\square$

$\square$

$\square$

\section{Quality of Life Goals}

$\square$ to reduce energy consumption in our home and in the farm/ranch operation

$\square$ to reduce family debt

$\square$ to provide support for our children's college education

$\square$ to provide financial or other support to community organizations

$\square$ to reduce household operating expenses

$\square$ to build an emergency fund

$\square$ to be involved in at least one significant community activity that is important to our family's goals, health, values, or well-being

$\square$ to build a retirement fund

$\square$ to grow crops or raise livestock during my retirement

$\square$ to enhance relationships with neighbors and the community

$\square$ to enhance health and well-being on the farm

$\square$

$\square$ 


\section{Statement of Goals, cont'd.}

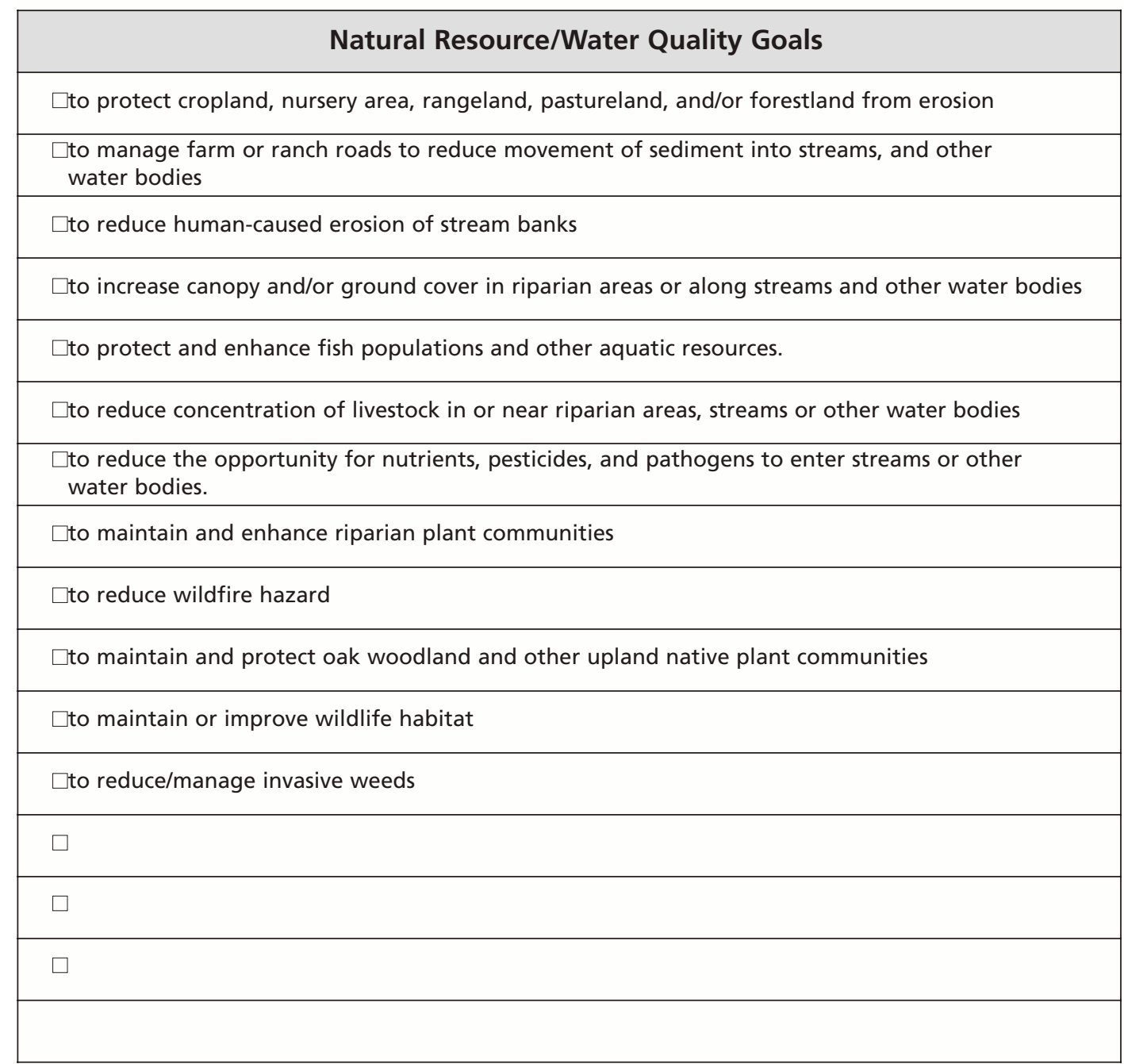




\section{REGIONAL AND LOCAL WATER QUALITY INFORMATION}

This section is a place for you to document information about your watershed, groundwater basin, and downstream waterbodies that has been collected by a variety of agencies. This information is documented in the following resources:

California Coastal Commission (CCC)

CCAs http:/ / www.coastal.ca.gov/nps/cca-nps.html

California Department of Pesticide Regulation (DPR)

GWPA Maps

http:/ / www.cdpr.ca.gov/docs/gwp/gwpamaps.htm

GWPA Lists by Legal Description

http://www.cdpr.ca.gov/docs/gwp/gwpa_lists.htm

National Oceanic and Atmospheric Administration (NOAA) -

National Marine Fisheries Service (NMFS) Protected Resources Division

ESUs http:// swr.ucsd.edu/psd/ps1inf.htm\#Salmon

State Water Resources Control Board (SWRCB) -

Regional Water Quality Control Board (RWQCB)

Beneficial Uses - Basin Plan

http:/ / www.swrcb.ca.gov/rwqcb3/BasinPlan/BP text/chapter 2/

figs $n$ tables/table 2-1.doc

Beneficial Use Support - California Water Quality Assessment Report 1998 -

Staff Report Part A

http://www.swrcb.ca.gov/general/publications/index.html\#Cc

Clean Water Act Section 303(d) List

http: / / www.swrcb.ca.gov/tmdl/ docs/2002reg3303dlist.pdf

CCAMP Monitoring Data http:// www.ccamp.org/ca/3/3.htm

\section{How to complete this section}

Draw from the above resources to complete this section. If you don't have access to one of these resources, contact your Watershed Coordinator or contact the agency directly. 
Regional and Local Water Quality Information, cont'd.

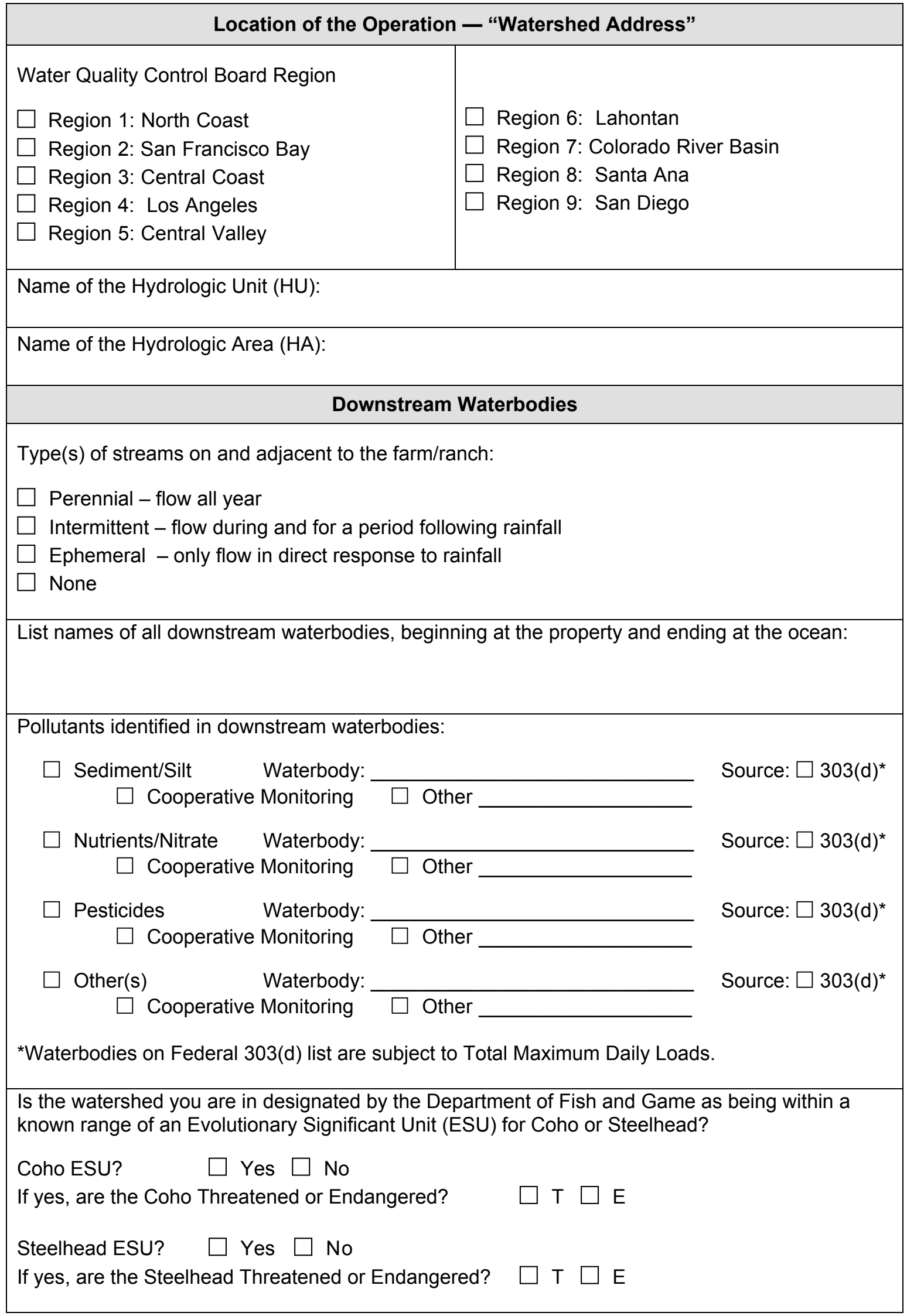


Regional and Local Water Quality Information, cont'd.

Is a coastal zone downstream of the operation designated by the California Coastal Commission as a proposed Critical Coastal Area (CCA)? $\square$ Yes $\square$ No

Groundwater Basin

Name and Number of the Groundwater Basin:

Is the farm/ranch within an area designated by the California Department of Pesticide Regulation as a Ground Water Protection Area (GWPA)? $\square$ Yes $\square$ No

Include maps that indicate your watershed, groundwater basin, and flow of water from your operation to the ocean. 


\section{FARM/RANCH MAP}

Facilities and Resources

Keep maps and photographs with Plan for reference

Indicate the acres within the boundary, number of each facility and hydrologic feature, and miles of road and fencing. Rough estimates are adequate for miles.

\begin{tabular}{|c|c|c|}
\hline $\begin{array}{l}\text { Shown on } \\
\text { map }\end{array}$ & Boundaries & Total Acres \\
\hline$\square$ & Farm or ranch boundary & \\
\hline$\square$ & -ーーーー-- & \\
\hline \multirow[t]{2}{*}{$\square$} & & \\
\hline & Buildings & Total Number \\
\hline$\square$ & Residence, offices & \\
\hline$\square$ & Barns/shops/outbuildings & \\
\hline$\square$ & Pesticide storage & \\
\hline$\square$ & Fertilizer storage & \\
\hline$\square$ & Petroleum storage & \\
\hline$\square$ & Dairy or other animal handling facilities & \\
\hline$\square$ & Livestock waste management facilities & \\
\hline$\square$ & 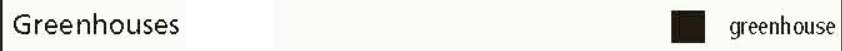 & \\
\hline$\square$ & Shade houses, other temporary structures & \\
\hline$\square$ & Soil handling/mixing, compost areas & \\
\hline$\square$ & Boiler rooms & \\
\hline$\square$ & Cold storage, postharvest handling & \\
\hline \multirow[t]{2}{*}{$\square$} & & \\
\hline & Structures & Total Number \\
\hline$\square$ & Equipment yards & \\
\hline$\square$ & Corrals & \\
\hline$\square$ & Feedlots & \\
\hline$\square$ & \begin{tabular}{ll|l|l|} 
Septic tanks, other bathroom facilities & ST & M & W \\
\end{tabular} & \\
\hline$\square$ & Stockwater storage tanks & \\
\hline$\square$ & Stockwater troughs & \\
\hline$\square$ & Erosion control structures 58 & \\
\hline$\square$ & & \\
\hline
\end{tabular}


Farm/Ranch Map, cont'd.

\begin{tabular}{|c|c|c|c|}
\hline & Fences and Roads & & Total Miles \\
\hline$\square$ & Fences & $x \quad x$ & \\
\hline$\square$ & Dirt road & 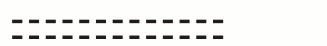 & \\
\hline$\square$ & Gravel road 59 & 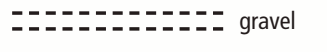 & \\
\hline$\square$ & Paved road & 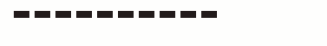 & \\
\hline \multirow[t]{2}{*}{$\square$} & & & \\
\hline & Hydrologic Features & & Total Number \\
\hline$\square$ & Irrigation ditches & $\rightarrow$ & \\
\hline$\square$ & Irrigation ditches, lined 59 & $\rightarrow \longrightarrow$ lined & \\
\hline$\square$ & Streams and creeks & & \\
\hline$\square$ & Springs & & \\
\hline$\square$ & Irrigation reservoirs & $\mathrm{R}$ & \\
\hline$\square$ & Recycling reservoirs 59 & $\mathrm{R}$ recycling & \\
\hline$\square$ & Irrigation settling ponds 59 & $\begin{array}{l}\text { settling } \\
\text { pond }\end{array}$ & \\
\hline$\square$ & Stockwater ponds & $\alpha$ & \\
\hline$\square$ & Tailwater recovery systems 59 & $\begin{array}{l}\text { tailwater } \\
\text { recovery } \\
\text { system }\end{array}$ & \\
\hline$\square$ & Bridges & $\frac{y}{1+1,1+1}$ & \\
\hline$\square$ & Stream crossings & \}$^{\text {FORD }}(-$ & \\
\hline$\square$ & Domestic wells 59 & $\begin{array}{l}\text { domestic } \\
\text { well }\end{array}$ & \\
\hline$\square$ & Irrigation wells & $-0-$ & \\
\hline$\square$ & Stockwater wells 59 & - well & \\
\hline$\square$ & & & \\
\hline
\end{tabular}




\section{SITE ASSESSMENT AND PRACTICES PLANNING}

You have completed the basin water quality information that lists important water bodies in your area and the water quality problems that have been identified for these water bodies. You have also created a map of your farm or ranch that lists land uses, facilities, and resources.

The following section can help identify areas of your farm or ranch where you've already implemented management practices to protect water quality. It can also help determine what areas of your farm or ranch can receive the most benefit from the implementation of new management practices. These items can be added to your map.

A trip around the property in a vehicle or on foot may be necessary to complete this assessment. Some of the assessment may involve accessing your pesticide use reports, or operations budget for nutrients applied to specific fields. Keep this section and the following self-evaluation section as a working document to record your decisions and your progress. You should keep records or take photographs before and after implementation to document changes that occur as a result of practices or groups of practices.

If you conclude that you need to make some changes, it may take you a while to decide how to proceed. You may want to compare practices that can accomplish the same thing. Not all practices listed may be applicable or available for your situation. Discuss these options with other farmers, consultants, or technical advisors from UCCE, NRCS, RCDs or other organizations. You should estimate costs of implementation. You may want to seek cost share funding with NRCS or other sources.

\section{How to complete this section:}

If you answer "yes" to any of the questions, look at the following table(s) for Management Practices. Select Practices that you are currently using or that you think might be useful. Update annually and keep notes that help with record keeping. If you would like to be more specific, you can record block designations, square footage, or acres of each selected Practice in the "location(s)" column. NRCS Conservation Practice Standards that you might want to use are listed where applicable. 59 
Site Assessment and Practices Planning-Sediment, cont'd.

\section{Managing Sediment}

Soil erosion and sediment deposition are primary contributors to lowered surface water quality from farmlands. In areas where there are steep slopes, erodible soils, and intense storm characteristics, sediment delivery from farmlands can be relatively high. Roads and other areas of disturbed ground where bare soils are susceptible to the erosive action of water and wind can also be major contributors of sediment to waterbodies.

\section{Upstream/Upslope Land Use}

S1. Is your property affected by sediment from upstream/upslope land uses?

$\square$ Yes $\square$ No

Notes:

\section{Practices to Manage Sediment from Upstream/Upslope}

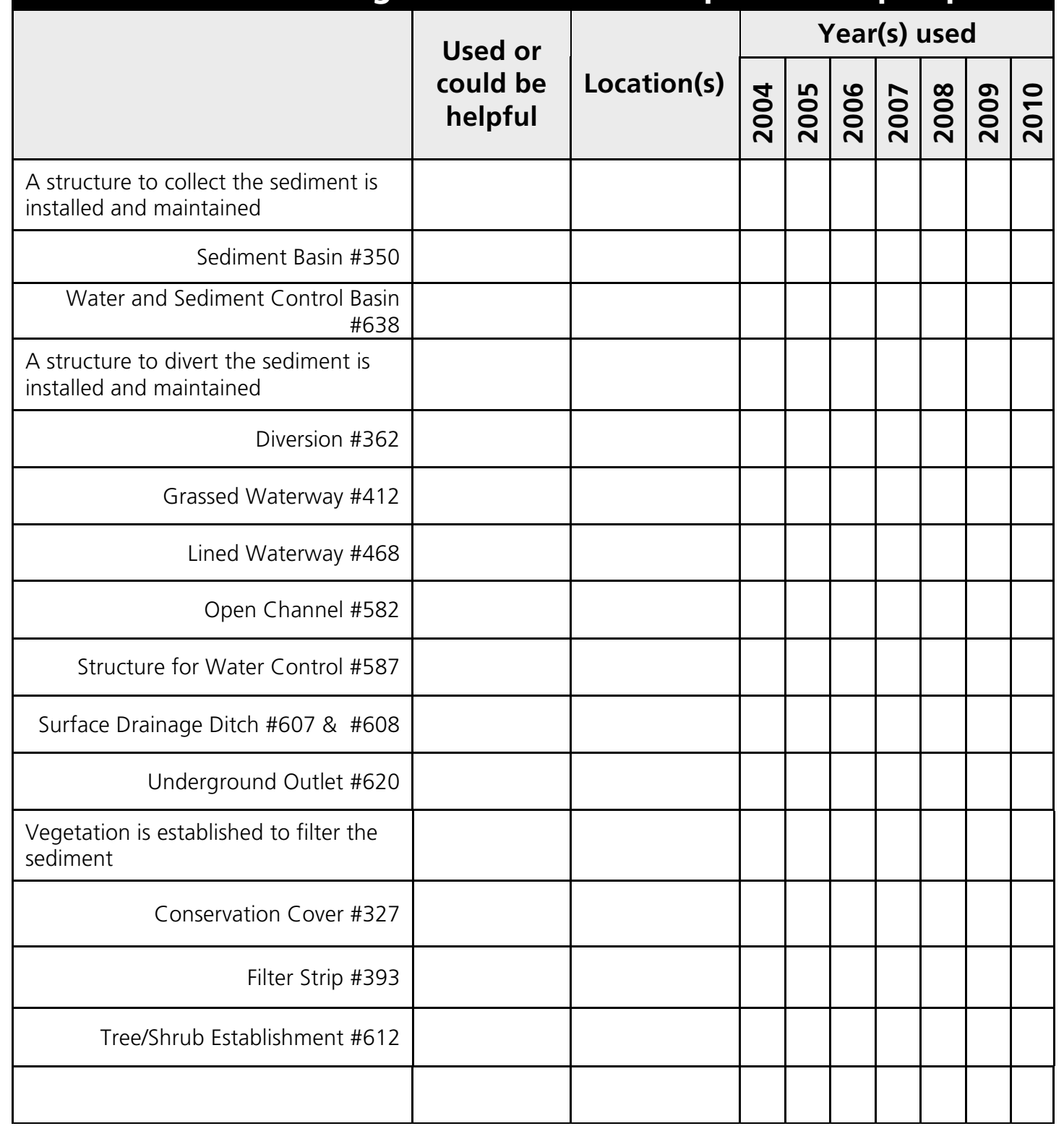


Site Assessment and Practices Planning-Sediment, cont'd.

\section{Fields and Other Growing Areas}

S2. Do you notice soil erosion from fields and other growing areas with steep slopes or long lengths of run?

$\square$ Yes $\square$ No

Notes:

\section{Develop a Field Layout to Minimize Erosion Potential}

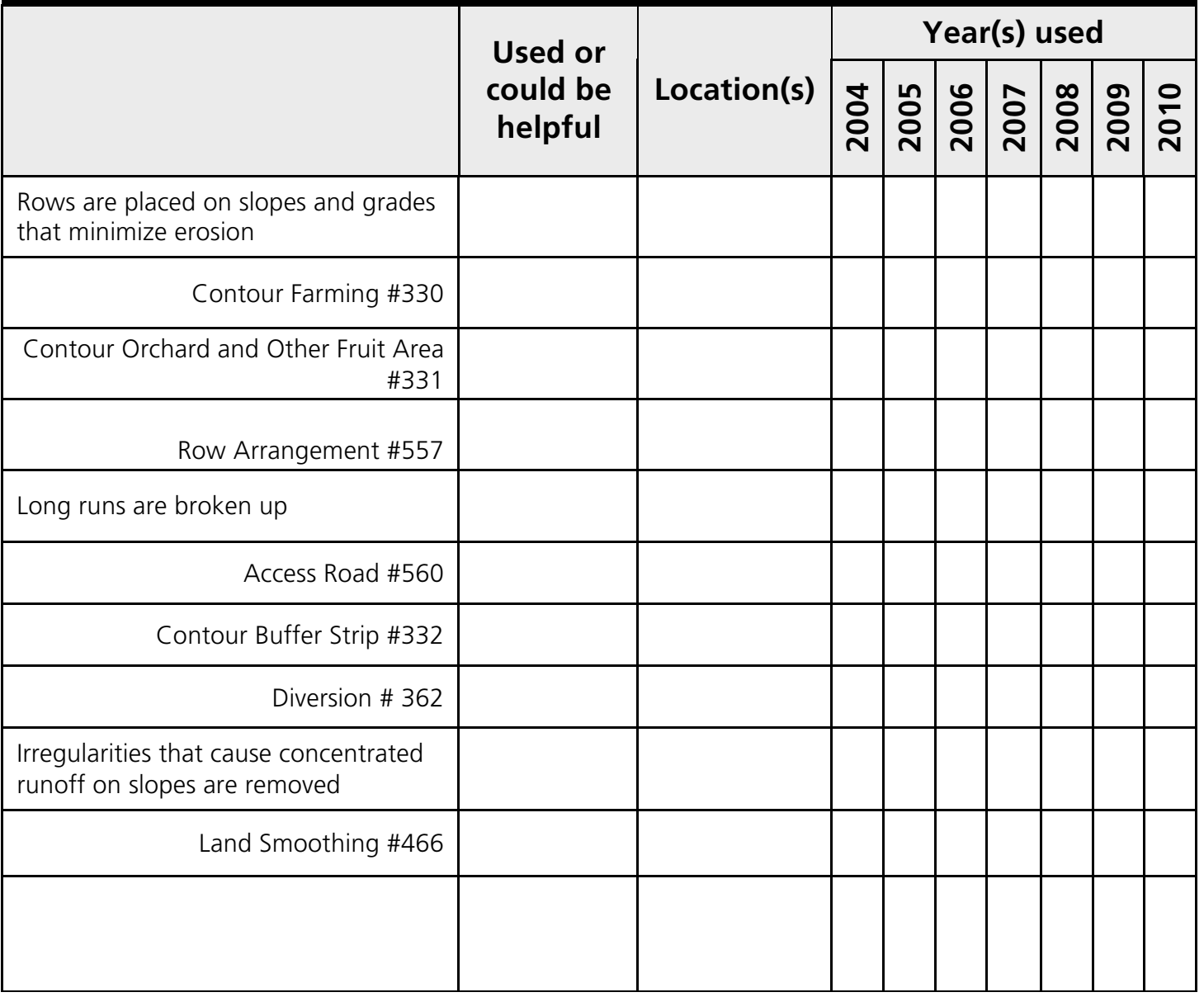


Site Assessment and Practices Planning-Sediment, cont'd.

S3. During rain events, do you notice soil erosion from fields with bare soil or sparse ground cover? $\square$ Yes $\square$ No

Notes:

\section{Cover Bare Fields to Reduce Rainfall Runoff Potential}

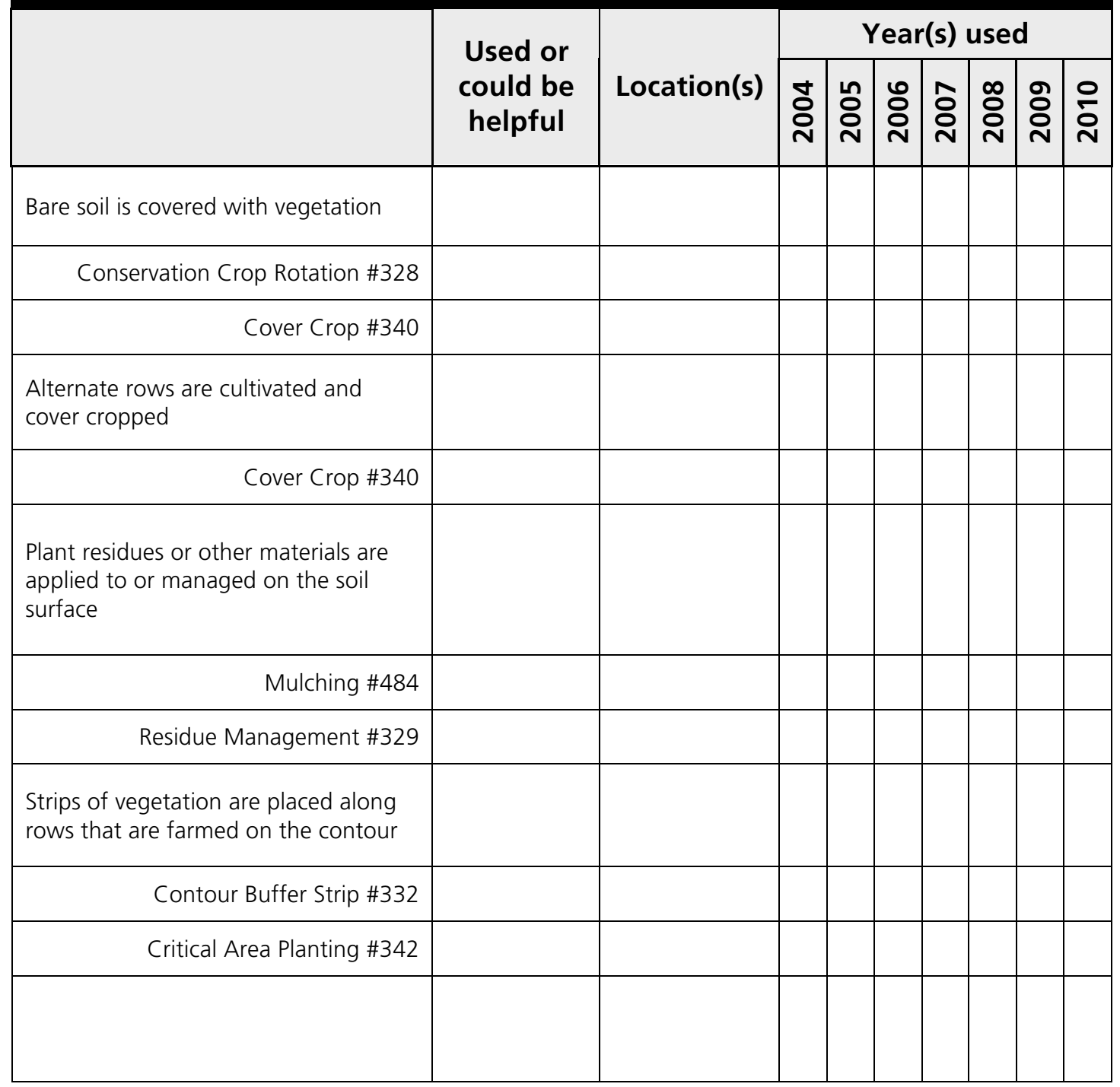


Site Assessment and Practices Planning-Sediment, cont'd.

S4. During irrigation, do you notice sediments in runoff from fields?

$\square$ Yes $\square$ No

Notes:

Manage Irrigation Water to Minimize Erosion Potential

\begin{tabular}{|c|c|c|c|c|c|c|c|c|c|}
\hline & \multirow{2}{*}{$\begin{array}{l}\text { Used or } \\
\text { could be } \\
\text { helpful }\end{array}$} & \multirow[b]{2}{*}{ Location(s) } & \multicolumn{7}{|c|}{ Year(s) used } \\
\hline & & & 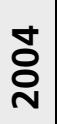 & @̊ & ஜ̊ & $\hat{ᄋ}$ & $\stackrel{\infty}{\circ}$ & 용 & $\stackrel{ }{\stackrel{0}{0}}$ \\
\hline \multicolumn{10}{|l|}{$\begin{array}{l}\text { Amendments are used to improve } \\
\text { infiltration - PAM, gypsum, organic } \\
\text { amendments }\end{array}$} \\
\hline \multicolumn{10}{|l|}{ Anionic Polyacrylamide (PAM) \#450 } \\
\hline \multicolumn{10}{|l|}{$\begin{array}{l}\text { Deep tillage is performed to fracture } \\
\text { restrictive soil layers and increase } \\
\text { deep percolation where leaching of } \\
\text { pollutants to groundwater is not a } \\
\text { significant risk }\end{array}$} \\
\hline \multicolumn{10}{|l|}{ Deep Tillage \#324 } \\
\hline \multicolumn{10}{|l|}{$\begin{array}{l}\text { Soil or substrate moisture status is } \\
\text { monitored using tensiometers or other } \\
\text { sensors }\end{array}$} \\
\hline \multicolumn{10}{|l|}{$\begin{array}{l}\text { The application rate of the irrigation } \\
\text { system (in/hr) is known }\end{array}$} \\
\hline \multicolumn{10}{|l|}{$\begin{array}{l}\text { Irrigation system is redesigned or } \\
\text { converted to another type }\end{array}$} \\
\hline \multicolumn{10}{|l|}{$\begin{array}{l}\text { Fields are graded for uniform } \\
\text { application of irrigation water }\end{array}$} \\
\hline \multicolumn{10}{|l|}{ Irrigation Land Leveling \#464 } \\
\hline Irrigation Water Management \#449 & & & & & & & & & \\
\hline & & & & & & & & & \\
\hline
\end{tabular}


Site Assessment and Practices Planning-Sediment, cont'd.

S5. During high winds, do you notice dust blowing from fields with bare soil or sparse ground cover or from field roads?

$\square$ Yes $\square$ No

Notes:

\begin{tabular}{|c|c|c|c|c|c|c|c|c|c|}
\hline & \multirow{2}{*}{$\begin{array}{l}\text { Used or } \\
\text { could be } \\
\text { helpful }\end{array}$} & \multirow[b]{2}{*}{ Location(s) } & \multicolumn{7}{|c|}{ Year(s) used } \\
\hline & & & ষ্ণ & 옹 & ஜ & 옹 & $\stackrel{\infty}{\circ}$ & 옹 & $\stackrel{\circ}{\circ}$ \\
\hline $\begin{array}{l}\text { Vegetation is established along the } \\
\text { field edges to shield the field from } \\
\text { wind }\end{array}$ & & & & & & & & & \\
\hline Hedgerow \#422 & & & & & & & & & \\
\hline Herbaceous Wind Barrier \#603 & & & & & & & & & \\
\hline $\begin{array}{l}\text { Windbreak/Shelterbelt } \\
\text { Establishment \#380 \& } 650\end{array}$ & & & & & & & & & \\
\hline $\begin{array}{l}\text { The bare soil is covered with } \\
\text { vegetation }\end{array}$ & & & & & & & & & \\
\hline Cover Crop \#340 & & & & & & & & & \\
\hline Conservation Crop Rotation \#328 & & & & & & & & & \\
\hline Residue Management \#329 & & & & & & & & & \\
\hline The soil surface is roughened & & & & & & & & & \\
\hline Cross Wind Ridges \#589A & & & & & & & & & \\
\hline Surface Roughening \#609 & & & & & & & & & \\
\hline $\begin{array}{l}\text { Road surfaces are protected with } \\
\text { mulch, gravel, water or an } \\
\text { environmentally safe dust suppressant }\end{array}$ & & & & & & & & & \\
\hline Access Road \#560 & & & & & & & & & \\
\hline Mulching \#484 & & & & & & & & & \\
\hline & & & & & & & & & \\
\hline
\end{tabular}


Site Assessment and Practices Planning-Sediment, cont'd.

\section{Container Grown Plants, Including Hydroponics}

S6. Do you grow plants in containers in a system that doesn't recover all applied water? $\square$ Yes $\square$ No

Notes:

\section{Reduce Erosion and Runoff in Container Grown Plants}

\begin{tabular}{|c|c|c|c|c|c|c|c|c|c|}
\hline & \multirow{2}{*}{$\begin{array}{l}\text { Used or } \\
\text { could be } \\
\text { helpful }\end{array}$} & \multirow[b]{2}{*}{ Location(s) } & \multicolumn{7}{|c|}{ Year(s) used } \\
\hline & & & ষ̊̊ & 옹 & ○̊ & ᄋ̊ & 足 & 옹 & 웅 \\
\hline $\begin{array}{l}\text { Plants are grouped to increase water } \\
\text { and nutrient use efficiency by } \\
\text { container size, container design, age, } \\
\text { canopy architecture, water and } \\
\text { nutrient requirements and/or salt } \\
\text { tolerance }\end{array}$ & & & & & & & & & \\
\hline $\begin{array}{l}\text { Plants are consolidated and irrigation } \\
\text { is shut off in unused portions }\end{array}$ & & & & & & & & & \\
\hline $\begin{array}{l}\text { Containers are filled and packed } \\
\text { uniformly }\end{array}$ & & & & & & & & & \\
\hline $\begin{array}{l}\text { Growing media and/or substrate is } \\
\text { selected for high water holding } \\
\text { capacity and adequate drainage and } \\
\text { aeration }\end{array}$ & & & & & & & & & \\
\hline $\begin{array}{l}\text { Growing media and/or substrate is } \\
\text { stored and mixed in a location } \\
\text { sheltered from wind and away from } \\
\text { drainage channels }\end{array}$ & & & & & & & & & \\
\hline $\begin{array}{l}\text { Mulch is used to protect ground } \\
\text { surface below containers from } \\
\text { erosion. }\end{array}$ & & & & & & & & & \\
\hline & & & & & & & & & \\
\hline
\end{tabular}


Site Assessment and Practices Planning-Sediment, cont'd.

\section{Roads and Roadside Ditches}

S7. Do you notice rills, gullies or headcuts running down the road?

$\square$ Yes $\square$ No

Notes:

S8. Do you notice water-loving vegetation present on the roadbed?

$\square$ Yes $\square$ No

Notes:

S9. Is an outboard berm channeling water down the road?

$\square$ Yes $\square$ No

Notes:

S10. Do you notice tension cracks on the road surface or outboard fill?

$\square$ Yes $\square$ No

Notes:

\section{Protect Road Surface from Concentrated Runoff}

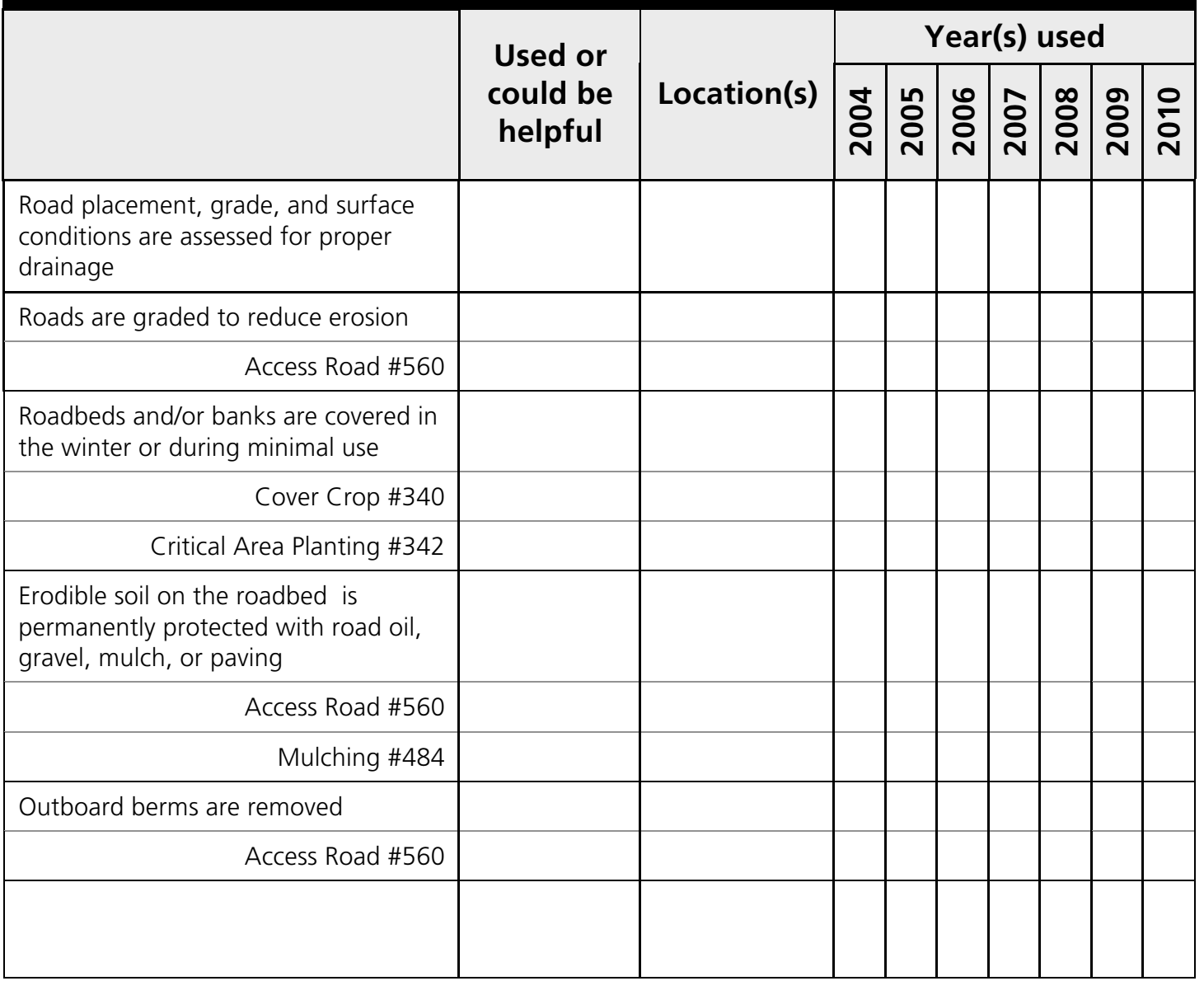


Site Assessment and Practices Planning-Sediment, cont'd.

S11. Is the road or ditch runoff causing erosion on land below the roadway?

$\square$ Yes $\square$ No

Notes:

S12. Are ditch banks or channels being eroded by water flow from greenhouses and other structures, fields or roads?

$\square$ Yes $\square$ No

Notes:

S13. Do you notice that the inboard ditch channel is being downcut?

$\square$ Yes $\square$ No

Notes:

S14. Is the inboard ditch channel obstructed, causing water to flow onto the road?

$\square$ Yes $\square$ No

Notes:

S15. Is overflow from a plugged culvert dierting water down the road surface?

$\square$ Yes $\square$ No

Notes:

S16. Do you see rockfall or slumping due to instability of the cutbank or hillslope above the roadway?

$\square$ Yes $\square$ No

Notes:

\section{Protect Ditches and Banks from Concentrated Flow of Runoff}

\begin{tabular}{|c|c|c|c|c|c|c|c|c|c|}
\hline & \multirow{2}{*}{$\begin{array}{l}\text { Used or } \\
\text { could be } \\
\text { helpful }\end{array}$} & \multirow[b]{2}{*}{ Location(s) } & \multicolumn{7}{|c|}{ Year(s) used } \\
\hline & & & ষ্ণ & 옹 & ঃ̊ & 용 & $\stackrel{\infty}{\circ}$ & 옹 & $\stackrel{\circ}{\circ}$ \\
\hline $\begin{array}{l}\text { Road placement, grade, and surface } \\
\text { conditions are assessed for proper } \\
\text { drainage }\end{array}$ & & & & & & & & & \\
\hline $\begin{array}{l}\text { Vegetation is established in eroding } \\
\text { roadside ditches }\end{array}$ & & & & & & & & & \\
\hline Grassed Waterway \#412 & & & & & & & & & \\
\hline $\begin{array}{l}\text { Eroding channels are protected with } \\
\text { geotextiles or rock. }\end{array}$ & & & & & & & & & \\
\hline Lined Channel \#468 & & & & & & & & & \\
\hline $\begin{array}{l}\text { Ditches and culverts provide adequate } \\
\text { drainage }\end{array}$ & & & & & & & & & \\
\hline Grade Stabilization Structure \#410 & & & & & & & & & \\
\hline Open Channel \#582 & & & & & & & & & \\
\hline Structure for Water Control \#587 & & & & & & & & & \\
\hline
\end{tabular}


Site Assessment and Practices Planning-Sediment, cont'd.

\begin{tabular}{|c|c|c|c|c|c|c|c|c|c|}
\hline & Used or & & & & lear & (s) & use & & \\
\hline & $\begin{array}{l}\text { could be } \\
\text { helpful }\end{array}$ & Location(s) & ষ্ঠ & 옹 & ஜ্ণ & 용 & 只 & 옹 & 응 \\
\hline $\begin{array}{l}\text { Ditches and culverts are kept clean of } \\
\text { debris }\end{array}$ & & & & & & & & & \\
\hline $\begin{array}{l}\text { Water is diverted away from unstable } \\
\text { slopes }\end{array}$ & & & & & & & & & \\
\hline Diversion \#362 & & & & & & & & & \\
\hline Unstable slopes are treated & & & & & & & & & \\
\hline Cut Bank Stabilization \#742 & & & & & & & & & \\
\hline & & & & & & & & & \\
\hline
\end{tabular}


Site Assessment and Practices Planning-Sediment, cont'd.

\section{Non-Cropped \& Non-Road Areas}

S14. Do you notice erosion or sediment loss from areas of bare soil in areas such as cut banks, field margins, between field blocks or greenhouses, on abandoned slopes, soil mixing/handling or compost areas, equipment yards, parking areas, and postharvest or cold storage facilities?

$\square$ Yes $\square$ No

Notes:

S15. Do you see signs of or the potential for sheet erosion, rill erosion, gullies, headcuts, mudslides, or landslides in steep non-cropped areas?

$\square$ Yes $\square$ No

Notes:

\section{Reduce Erosion from Non-cropped Areas}

\begin{tabular}{|c|c|c|c|c|c|c|c|c|c|}
\hline \multirow{2}{*}{\multicolumn{2}{|c|}{$\begin{array}{c}\text { Used or } \\
\text { could be } \\
\text { helpful }\end{array}$}} & \multirow[b]{2}{*}{ Location(s) } & \multicolumn{7}{|c|}{ Year(s) used } \\
\hline & & & ষ্ণ & 융 & ○ั & 尺̊ & $\stackrel{\infty}{\circ}$ & 용 & $\stackrel{ }{\circ}$ \\
\hline \multicolumn{10}{|c|}{ Protect Soil } \\
\hline \multicolumn{10}{|l|}{$\begin{array}{l}\text { Bare soil is covered with vegetation or } \\
\text { mulch }\end{array}$} \\
\hline \multicolumn{10}{|l|}{ Conservation Cover \#327 } \\
\hline \multicolumn{10}{|l|}{ Critical Area Planting \#342 } \\
\hline \multicolumn{10}{|l|}{ Filter Strip \#393 } \\
\hline \multicolumn{10}{|l|}{ Hedgerow Planting \#422 } \\
\hline \multicolumn{10}{|l|}{ Mulching \#484 } \\
\hline \multicolumn{10}{|l|}{ Range Planting \#550 } \\
\hline \multicolumn{10}{|l|}{ Tree/Shrub Establishment \#612 } \\
\hline \multicolumn{10}{|l|}{$\begin{array}{l}\text { Vegetation is allowed to reestablish by } \\
\text { excluding animals, people or vehicles }\end{array}$} \\
\hline \multicolumn{10}{|l|}{ Use Exclusion \#472 } \\
\hline \multicolumn{10}{|c|}{ Regrade Potential Problem Areas } \\
\hline \multicolumn{10}{|l|}{$\begin{array}{l}\text { Potential landslide areas are stabilized } \\
\text { by reducing and/or supporting the } \\
\text { slope }\end{array}$} \\
\hline \multicolumn{10}{|l|}{ Cut Bank Stabilization \#742 } \\
\hline \multicolumn{10}{|l|}{ Landslide Treatment \#453 } \\
\hline \multicolumn{10}{|l|}{ Gullies are stabilized or reshaped } \\
\hline \multicolumn{10}{|l|}{ Critical Area Planting \#342 } \\
\hline \multicolumn{10}{|l|}{ Grade Stabilization Structure \#410 } \\
\hline Structure for Water Control \#587 & & & & & & & & & \\
\hline & & & & & & & & & \\
\hline
\end{tabular}


Site Assessment and Practices Planning-Sediment, cont'd.

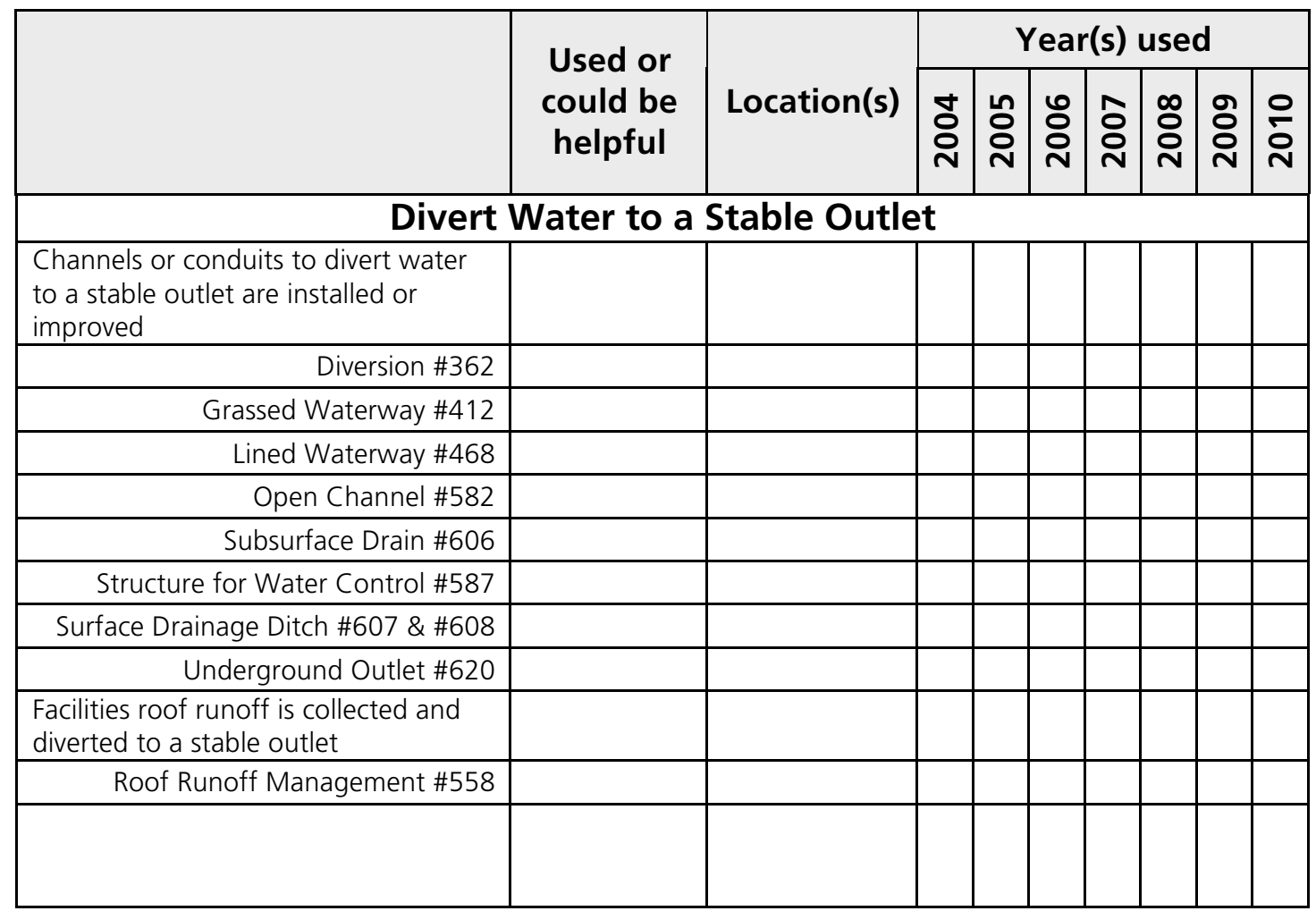


Site Assessment and Practices Planning-Sediment, cont'd.

\section{Sediment Leaving the Operation}

S16. Do you notice sediment moving off the farm after irrigation and/or storm events?

$\square$ Yes $\square$ No

Notes:

S17. Do you notice sediment accumulating in ditches, channels, ponds, or other waterways downstream of the farm?

$\square$ Yes $\square$ No

Notes:

\section{Detain or Filter Eroded Sediment Leaving the Operation}

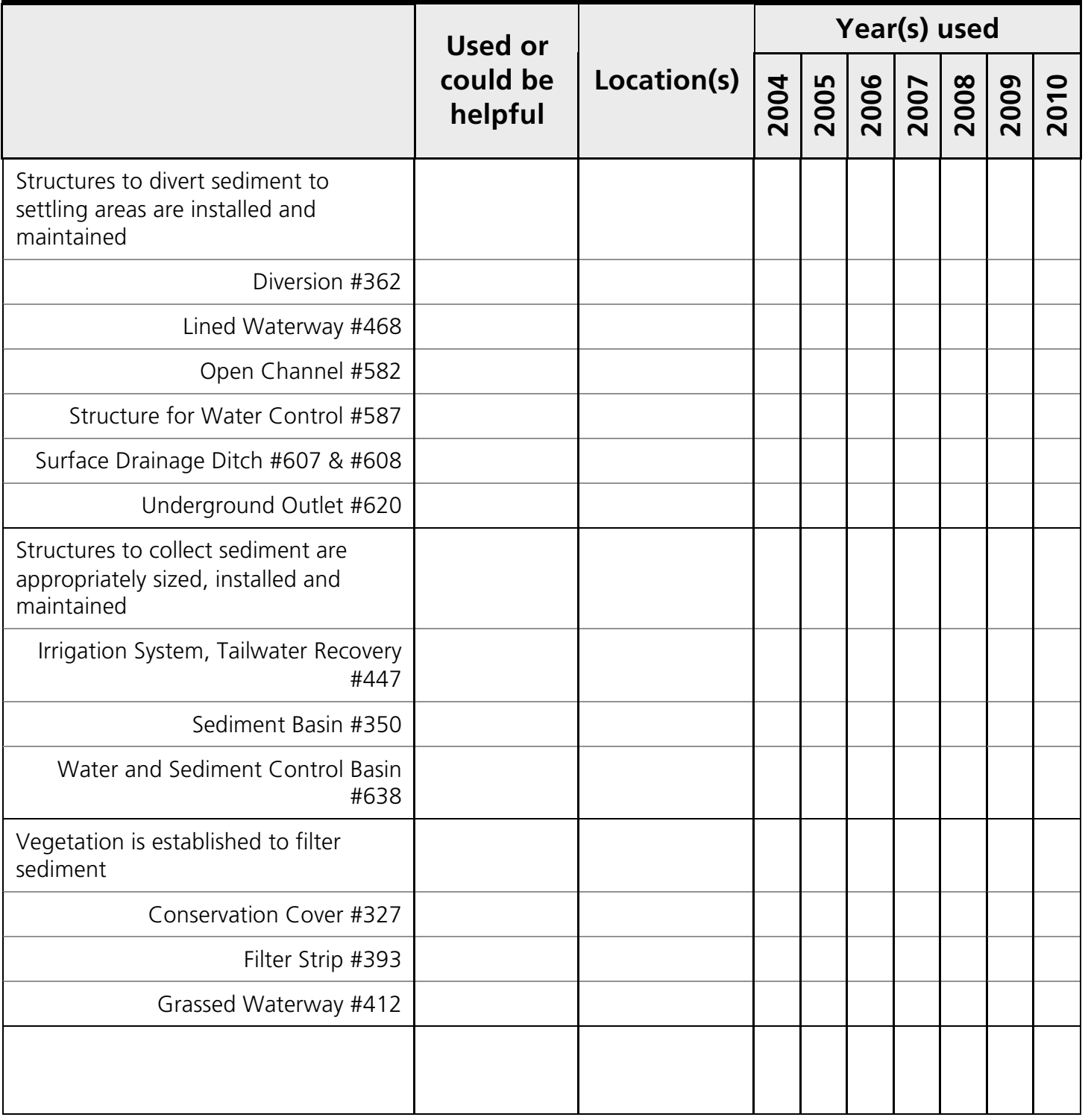


Site Assessment and Practices Planning-Sediment, cont'd.

\section{Managing Irrigation}

Efficient irrigation management maximizes water use for crop production and minimizes water losses caused by runoff, evaporation, and deep percolation. A portion of the water applied during an irrigation benefits crop growth by providing moisture for transpiration, preventing the build up of salts in the root zone, and moderating the air temperature around the crop. The remainder of the applied water that is lost through run-off and deep percolation not only wastes water, energy, and fertilizer, but can also transport sediments, nutrients and pesticides into ground and surface water supplies.

I1. Does tailwater or runoff water leave the operation during irrigation events?

$\square$ Yes $\square$ No

Notes:

12. Could you irrigate more efficiently to reduce the amount of water that leaches out of the root zone to eventually reach the groundwater?

$\square$ Yes $\square$ No

Notes:

\section{Manage Irrigation Water for Maximum Efficiency}

\begin{tabular}{|c|c|c|c|c|c|c|c|c|c|}
\hline & \multirow{2}{*}{$\begin{array}{l}\text { Used or } \\
\text { could be } \\
\text { helpful }\end{array}$} & \multirow[b]{2}{*}{ Location(s) } & \multicolumn{7}{|c|}{ Year(s) used } \\
\hline & & & ষ্ণ & 号 & ஜ & 욤 & 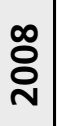 & 옹 & 응 \\
\hline \multicolumn{10}{|c|}{ Maximize Irrigation System Efficiency } \\
\hline \multicolumn{10}{|l|}{$\begin{array}{l}\text { Irrigation efficiency is evaluated by an } \\
\text { irrigation mobile lab, UCCE, or a } \\
\text { consultant }\end{array}$} \\
\hline \multicolumn{10}{|l|}{ Irrigation Water Management \#449 } \\
\hline \multicolumn{10}{|l|}{$\begin{array}{l}\text { Regular system maintenance is } \\
\text { performed }\end{array}$} \\
\hline \multicolumn{10}{|l|}{$\begin{array}{l}\text { Irrigators are trained in practices that } \\
\text { promote efficient irrigation }\end{array}$} \\
\hline \multicolumn{10}{|l|}{$\begin{array}{l}\text { Amendments are used to improve } \\
\text { infiltration - PAM, gypsum, organic } \\
\text { amendments }\end{array}$} \\
\hline \multicolumn{10}{|l|}{ Anionic Polyacrylamide (PAM) \#450 } \\
\hline \multicolumn{10}{|l|}{$\begin{array}{l}\text { Deep tillage is performed to fracture } \\
\text { restrictive soil layers and increase } \\
\text { deep percolation where leaching of } \\
\text { pollutants to groundwater is not a } \\
\text { significant risk }\end{array}$} \\
\hline Deep Tillage \#324 & & & & & & & & & \\
\hline & & & & & & & & & \\
\hline
\end{tabular}


Site Assessment and Practices Planning-Sediment, cont'd.

\begin{tabular}{|c|c|c|c|c|c|c|c|c|c|}
\hline & \multirow{2}{*}{$\begin{array}{l}\text { Used or } \\
\text { could be } \\
\text { helpful }\end{array}$} & \multirow[b]{2}{*}{ Location(s) } & \multicolumn{7}{|c|}{ Year(s) used } \\
\hline & & & ষ্ণ & 号 & ○ & ¿̊̀ & $\begin{array}{l}\infty \\
\stackrel{\circ}{\circ} \\
\text { N }\end{array}$ & 유 & 웅 \\
\hline \multicolumn{10}{|c|}{ Optimize Irrigation Scheduling } \\
\hline \multicolumn{10}{|l|}{$\begin{array}{l}\text { Daily water use is estimated using } \\
\text { resources such as CIMIS data, } \\
\text { evapotransporation (ET), atmometers } \\
\text { and/or irrigation records }\end{array}$} \\
\hline \multicolumn{10}{|l|}{$\begin{array}{l}\text { Soil or substrate moisture status is } \\
\text { monitored using tensiometers or other } \\
\text { sensors }\end{array}$} \\
\hline \multicolumn{10}{|l|}{$\begin{array}{l}\text { Irrigations are scheduled during times } \\
\text { that minimize ET losses }\end{array}$} \\
\hline \multicolumn{10}{|l|}{$\begin{array}{l}\text { The application rate of the irrigation } \\
\text { system (in/hr) is known }\end{array}$} \\
\hline \multicolumn{10}{|l|}{ Plant rooting depths are known } \\
\hline \multicolumn{10}{|l|}{$\begin{array}{l}\text { The irrigation schedule is adjusted to } \\
\text { account for the leaching fraction and } \\
\text { distribution uniformity of the system }\end{array}$} \\
\hline \multicolumn{10}{|l|}{$\begin{array}{l}\text { Timers automatically shut off irrigation } \\
\text { after a prescribed time }\end{array}$} \\
\hline \multicolumn{10}{|l|}{$\begin{array}{l}\text { Records are kept of the irrigation } \\
\text { schedule and water applied during } \\
\text { each irrigation }\end{array}$} \\
\hline \multicolumn{10}{|c|}{ Optimize Irrigation System Design } \\
\hline \multicolumn{10}{|l|}{$\begin{array}{l}\text { Irrigation system is properly designed } \\
\text { and maintained or is converted to } \\
\text { another type }\end{array}$} \\
\hline \multicolumn{10}{|l|}{ Irrigation Water Management \#449 } \\
\hline \multicolumn{10}{|l|}{ Irrigation System, Microirrigation \#441 } \\
\hline \multicolumn{10}{|l|}{ Irrigation System, Sprinkler \#442 } \\
\hline \multicolumn{10}{|l|}{$\begin{array}{l}\text { Fields are graded for uniform } \\
\text { application of irrigation water }\end{array}$} \\
\hline \multicolumn{10}{|l|}{ Irrigation Land Leveling \#464 } \\
\hline \multicolumn{10}{|l|}{$\begin{array}{l}\text { Irrigation water conveyance system } \\
\text { (main, canals, etc...) is properly } \\
\text { designed and maintained or upgraded }\end{array}$} \\
\hline $\begin{array}{r}\text { Irrigation Water Conveyance Pipeline } \\
\# 430\end{array}$ & & & & & & & & & \\
\hline
\end{tabular}


Site Assessment and Practices Planning-Sediment, cont'd.

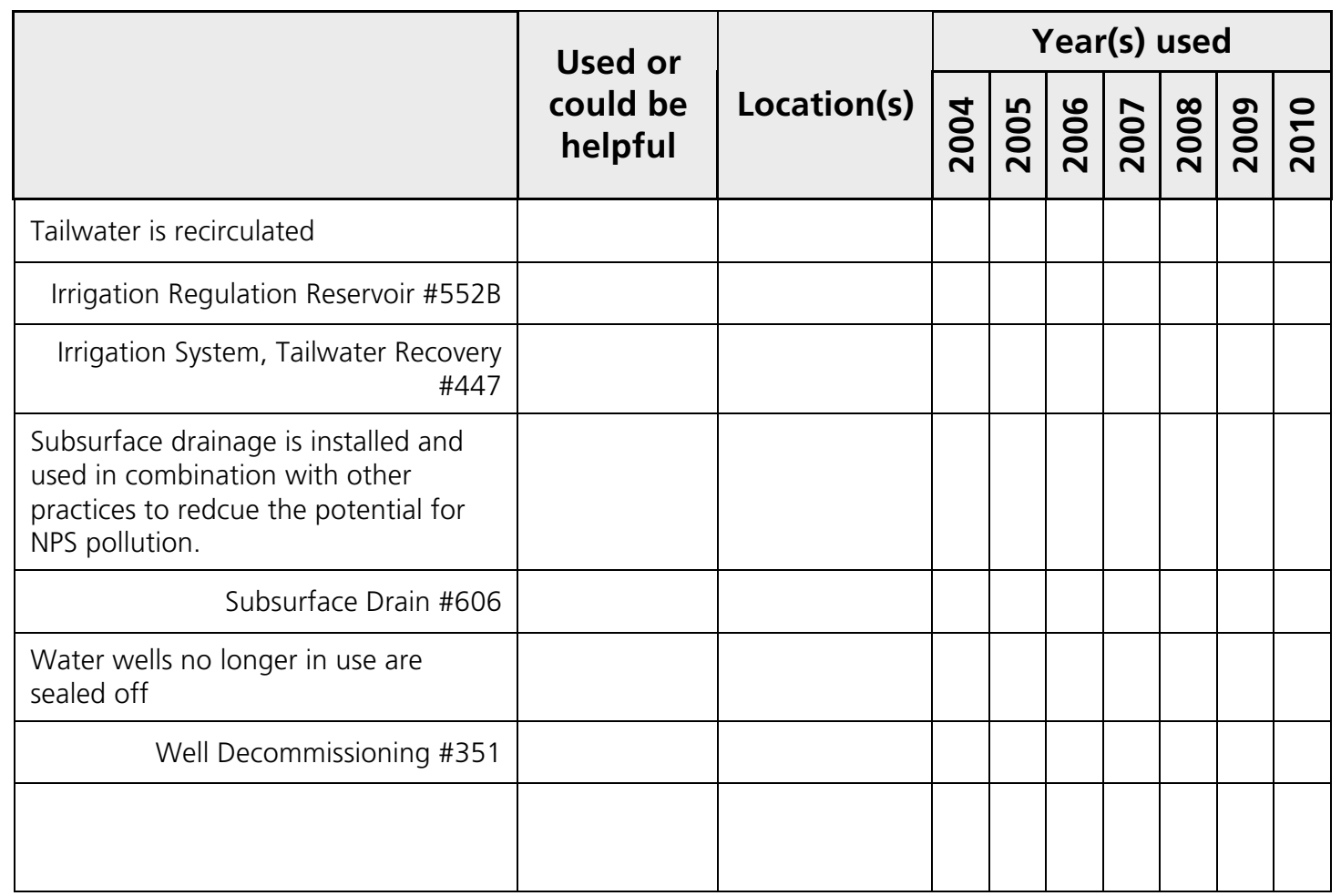


Site Assessment and Practices Planning-Sediment, cont'd.

\section{Are some areas furrow or flood irrigated?}

$\square$ Yes $\square$ No

Notes:

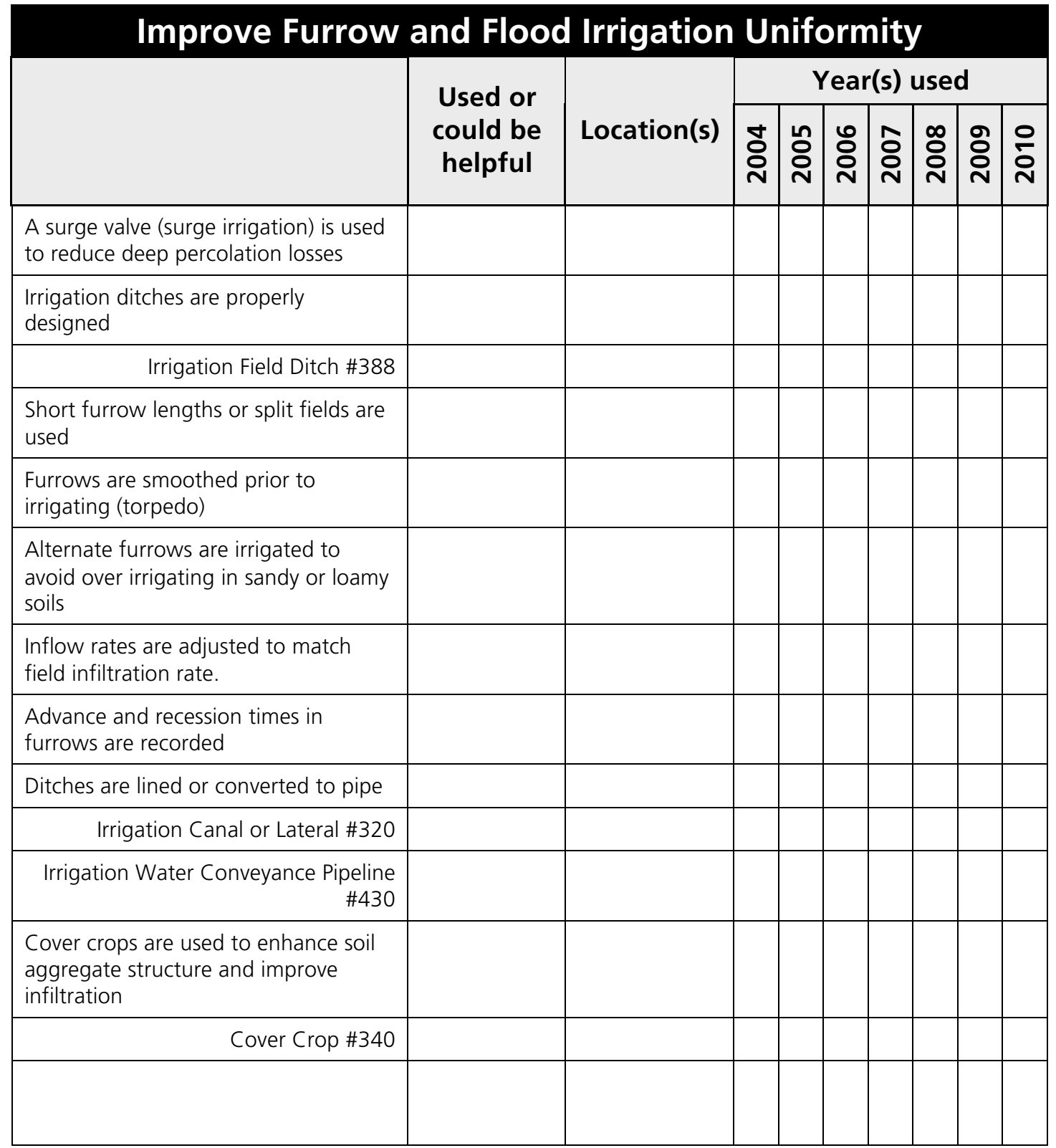


Site Assessment and Practices Planning-Sediment, cont'd.

\section{Are some areas irrigated with sprinklers or microsprinklers?}

$\square$ Yes $\square$ No

Notes:

\section{Improve Sprinkler and Microsprinkler Irrigation Uniformity}

\begin{tabular}{|c|c|c|c|c|c|c|c|c|c|}
\hline & & & & & ear & (s) & use & & \\
\hline & $\begin{array}{l}\text { could be } \\
\text { helpful }\end{array}$ & Location(s) & 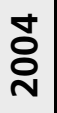 & $\stackrel{\text { ㅇ }}{\circ}$ & ஜ & 용 & $\stackrel{\infty}{\circ}$ & 옹 & $\stackrel{\circ}{\circ}$ \\
\hline Pulse irrigation is used & & & & & & & & & \\
\hline $\begin{array}{l}\text { Appropriate system pressure is } \\
\text { maintained }\end{array}$ & & & & & & & & & \\
\hline $\begin{array}{l}\text { System flow rate and pressures (heac } \\
\text { and tail) are recorded }\end{array}$ & & & & & & & & & \\
\hline $\begin{array}{l}\text { Leaks on mains and laterals are } \\
\text { repaired }\end{array}$ & & & & & & & & & \\
\hline Sprinkler heads are maintained & & & & & & & & & \\
\hline $\begin{array}{l}\text { Sprinkler heads with a high uniformi } \\
\text { rating are used }\end{array}$ & & & & & & & & & \\
\hline $\begin{array}{l}\text { Appropriate nozzle sizes are selected } \\
\text { for lateral spacing and head pattern }\end{array}$ & & & & & & & & & \\
\hline Uniform nozzle sizes are used & & & & & & & & & \\
\hline $\begin{array}{l}\text { Flow control nozzles are used when } \\
\text { pressure is too high or variable }\end{array}$ & & & & & & & & & \\
\hline $\begin{array}{l}\text { Consistent riser heights are used and } \\
\text { risers are maintained to remain } \\
\text { perpendicular to the ground }\end{array}$ & & & & & & & & & \\
\hline $\begin{array}{l}\text { Microsprinklers with low pressure } \\
\text { shut-off valves are used to improve } \\
\text { uniformity on sloping runs }\end{array}$ & & & & & & & & & \\
\hline $\begin{array}{l}\text { In greenhouses, traveling sprinkler } \\
\text { booms are used to increase } \\
\text { distribution uniformity }\end{array}$ & & & & & & & & & \\
\hline $\begin{array}{l}\text { Starting location of hand move lines } \\
\text { are offset between irrigations to } \\
\text { increase uniformity throughout the } \\
\text { growing season }\end{array}$ & & & & & & & & & \\
\hline Lateral hose runs are minimized & & & & & & & & & \\
\hline $\begin{array}{l}\text { System is operated in low-wind } \\
\text { conditions }\end{array}$ & & & & & & & & & \\
\hline
\end{tabular}


Site Assessment and Practices Planning-Sediment, cont'd.

\begin{tabular}{|c|c|c|c|c|c|c|c|c|c|}
\hline & \multirow{2}{*}{$\begin{array}{l}\text { Used or } \\
\text { could be } \\
\text { helpful }\end{array}$} & \multirow[b]{2}{*}{ Location(s) } & \multicolumn{7}{|c|}{ Year(s) used } \\
\hline & & & ষ্ণ & 옹 & ○̊ & 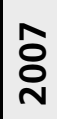 & 足 & 용 & 응 \\
\hline \multicolumn{10}{|l|}{$\begin{array}{l}\text { Vegetation is established along field } \\
\text { edges to shield from wind }\end{array}$} \\
\hline \multicolumn{10}{|l|}{ Herbaceous Wind Barrier \#603 } \\
\hline \multicolumn{10}{|l|}{ Windbreak/Shelterbelt \#380 \& \#650 } \\
\hline \multicolumn{10}{|l|}{$\begin{array}{l}\text { Irrigations are ended if significant } \\
\text { runoff occurs }\end{array}$} \\
\hline \multicolumn{10}{|l|}{$\begin{array}{l}\text { Cover crops are used to enhance soil } \\
\text { aggregate structure and improve } \\
\text { infiltration }\end{array}$} \\
\hline Cover Crop \#340 & & & & & & & & & \\
\hline & & & & & & & & & \\
\hline
\end{tabular}


Site Assessment and Practices Planning-Sediment, cont'd.

\section{Are some areas drip irrigated? \\ $\square$ Yes $\square$ No}

Notes:

\begin{tabular}{|c|c|c|c|c|c|c|c|c|c|}
\hline \multicolumn{10}{|c|}{ Improve Drip Irrigation Uniformity } \\
\hline & $\begin{array}{l}\text { Used or } \\
\text { could be } \\
\text { helpful }\end{array}$ & Location(s) & ষ্ণ & ㅇํㅇ & ஜ̊ & ᄋ్ & $\stackrel{\infty}{\circ}$ & 옹 & 응 \\
\hline $\begin{array}{l}\text { Drip tape and emitters are used with } \\
\text { an application rate that matches } \\
\text { system design, soil or substrate type, } \\
\text { and crop needs }\end{array}$ & & & & & & & & & \\
\hline $\begin{array}{l}\text { The water supply is evaluated for high } \\
\text { bicarbonates that can cause clogging }\end{array}$ & & & & & & & & & \\
\hline $\begin{array}{l}\text { A filter is selected that filters the } \\
\text { mineral and sand particles in the water } \\
\text { supply }\end{array}$ & & & & & & & & & \\
\hline Filters are regularly flushed/cleaned & & & & & & & & & \\
\hline Lateral lines are flushed regularly & & & & & & & & & \\
\hline $\begin{array}{l}\text { Lateral lines are periodically } \\
\text { chlorinated to prevent bacterial and } \\
\text { algal build-up and root intrusion into } \\
\text { emitters }\end{array}$ & & & & & & & & & \\
\hline $\begin{array}{l}\text { Emitters are regularly checked to } \\
\text { ensure they are delivering water to } \\
\text { plants }\end{array}$ & & & & & & & & & \\
\hline $\begin{array}{l}\text { Leaks on mains and laterals are } \\
\text { repaired }\end{array}$ & & & & & & & & & \\
\hline $\begin{array}{l}\text { Emitters with shut-off valves to isolate } \\
\text { unused containers or benches are } \\
\text { used }\end{array}$ & & & & & & & & & \\
\hline $\begin{array}{l}\text { Drip tape with a small emitter } \\
\text { discharge exponent is used }\end{array}$ & & & & & & & & & \\
\hline Pulse irrigation is used & & & & & & & & & \\
\hline $\begin{array}{l}\text { A pressure regulator is used for each } \\
\text { submain }\end{array}$ & & & & & & & & & \\
\hline $\begin{array}{l}\text { Pressures of submains are regularly } \\
\text { adjusted }\end{array}$ & & & & & & & & & \\
\hline $\begin{array}{l}\text { Pressure compensating emitters are } \\
\text { used }\end{array}$ & & & & & & & & & \\
\hline $\begin{array}{l}\text { Cover crops are used to enhance soil } \\
\text { aggregate structure and improve } \\
\text { infiltration }\end{array}$ & & & & & & & & & \\
\hline Cover Crop \#340 & & & & & & & & & \\
\hline & & & & & & & & & \\
\hline
\end{tabular}


Site Assessment and Practices Planning-Sediment, cont'd.

\section{Managing Pesticides}

Pesticides that move from their site of application into surface or groundwater can affect the beneficial uses of water through their potential impact on human and animal health, and on nontarget organisms. Wind and water erosion of soil, or drift from pesticide applications may contribute to pesticide movement away from the target area. Pesticides may enter surface waters in irrigation return flows and tile drainage either as water-soluble residuals or adsorbed to sediments. Groundwaters in agricultural areas may also be subject to pollution from pesticides when deep percolation from irrigated land carries water-soluble pesticides to the groundwater. Many practices in this section fall under NRCS Conservation Practice Standard Pest Management \#595. Consult other sources such as the UC Integrated Pest Management (IPM) Pest Management Guidelines for crop-specific IPM practices and alternatives to pesticide use http://www.ipm.ucdavis.edu.

\section{Pesticide Management Program}

P1. Does your pest management program have the potential to impact water quality? $\square$ Yes $\square$ No

Notes:

\section{Use IPM to Make Informed Pesticide Management Decisions http://www.imp.ucdavis.edu}

\begin{tabular}{|c|c|c|c|c|c|c|c|c|c|}
\hline & \multirow{2}{*}{$\begin{array}{l}\text { Used or } \\
\text { could be } \\
\text { helpful }\end{array}$} & \multirow[b]{2}{*}{ Location(s) } & \multicolumn{7}{|c|}{ Year(s) used } \\
\hline & & & ষ্ণ & 옹 & ஜ̊ & ¿্ণ & $\stackrel{\infty}{\circ}$ & 옹 & 응 \\
\hline \multicolumn{10}{|c|}{ Prepare Site and Use Plant Materials to Promote Crop Health } \\
\hline \multicolumn{10}{|l|}{$\begin{array}{l}\text { Fields are designed or managed to } \\
\text { reduce water related stress }\end{array}$} \\
\hline \multicolumn{10}{|l|}{ Bedding \#310 } \\
\hline \multicolumn{10}{|l|}{ Irrigation Land Leveling \#464 } \\
\hline \multicolumn{10}{|l|}{ Irrigation Water Management \#449 } \\
\hline \multicolumn{10}{|l|}{$\begin{array}{l}\text { Container media is selected to reduce } \\
\text { water related stress }\end{array}$} \\
\hline \multicolumn{10}{|l|}{ Resistant varieties are planted } \\
\hline \multicolumn{10}{|l|}{$\begin{array}{l}\text { Crop rotations are used to break pest } \\
\text { population cycles }\end{array}$} \\
\hline \multicolumn{10}{|l|}{ Conservation Crop Rotation \#328 } \\
\hline \multicolumn{10}{|l|}{$\begin{array}{l}\text { Cover crops are used to promote soil } \\
\text { health and reduce weeds, insects, and } \\
\text { pathogens }\end{array}$} \\
\hline \multicolumn{10}{|l|}{ Cover Crops \#340 } \\
\hline $\begin{array}{l}\text { Non-cropped areas are managed } \\
\text { (planted, paved or mulched) to } \\
\text { discourage weeds }\end{array}$ & & & & & & & & & \\
\hline & & & & & & & & & \\
\hline
\end{tabular}


Site Assessment and Practices Planning-Sediment, cont'd.

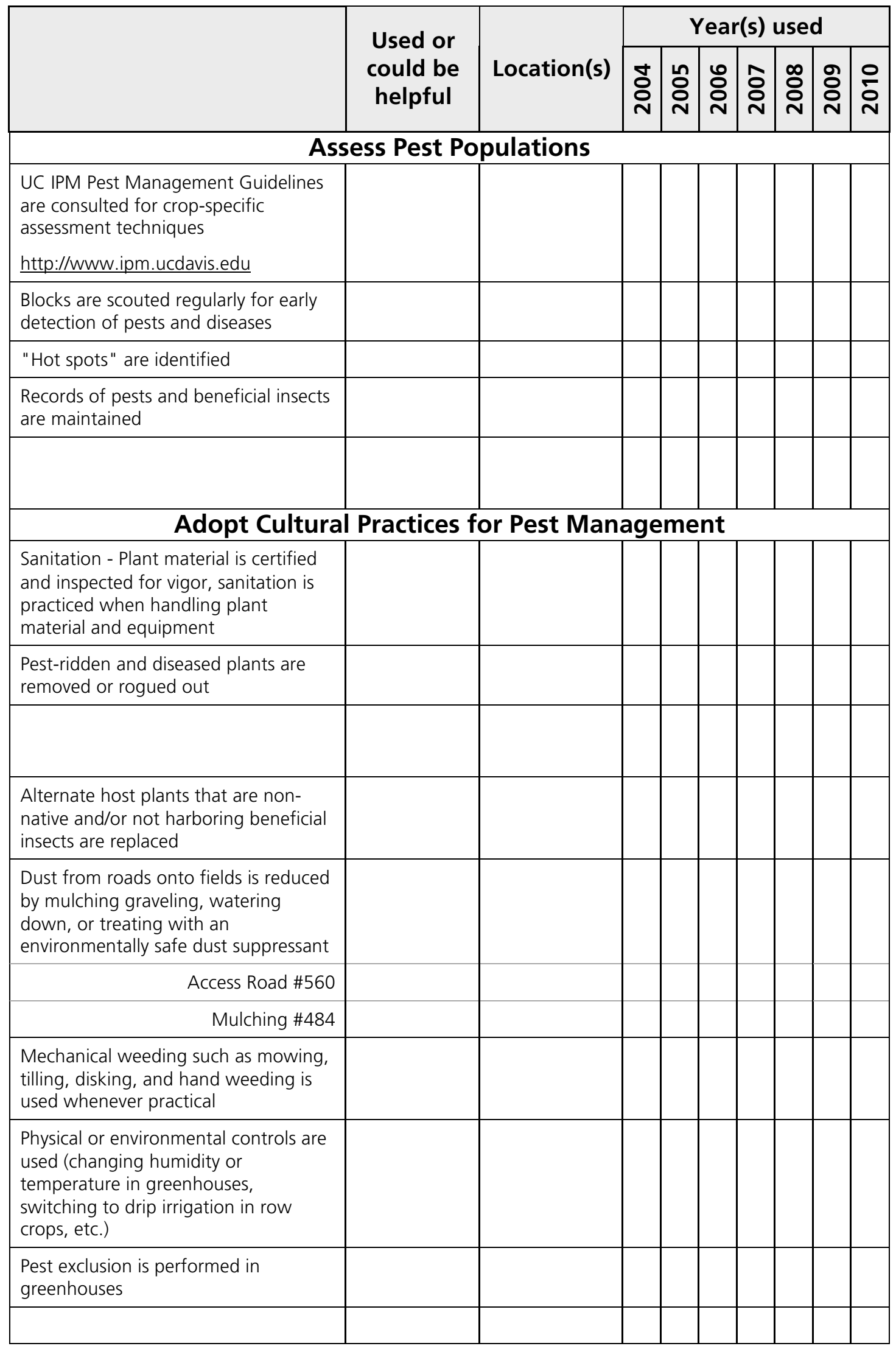


Site Assessment and Practices Planning-Sediment, cont'd.

\begin{tabular}{|c|c|c|c|c|c|c|c|c|c|}
\hline & \multirow{2}{*}{$\begin{array}{l}\text { Used or } \\
\text { could be } \\
\text { helpful }\end{array}$} & \multirow[b]{2}{*}{ Location(s) } & \multicolumn{7}{|c|}{ Year(s) used } \\
\hline & & & 官 & in & ○ & O্ঠি & $\stackrel{\infty}{\stackrel{N}{~}}$ & 용 & $\frac{0}{8}$ \\
\hline \multicolumn{10}{|c|}{ Adopt Biological Control Practices for Pest Management } \\
\hline \multicolumn{10}{|l|}{$\begin{array}{l}\text { Biological controls are used to control } \\
\text { pest populations, where possible }\end{array}$} \\
\hline \multicolumn{10}{|l|}{$\begin{array}{l}\text { Populations of beneficial insects are } \\
\text { considered when making pesticide } \\
\text { selection }\end{array}$} \\
\hline \multicolumn{10}{|c|}{ Make Efficient Pest Control Decisions } \\
\hline \multicolumn{10}{|c|}{\begin{tabular}{l|l|l|l} 
UC IPM Pest Management Guidelines & & & \\
are consulted for alternatives to & & \\
chemical pest control, or for reduced & & & \\
risk pesticide selections. & & & \\
http://www.ipm.ucdavis.edu & & &
\end{tabular}} \\
\hline \multicolumn{10}{|l|}{$\begin{array}{l}\text { Compatible pesticides such as selective } \\
\text { pesticides are used when beneficial } \\
\text { insects are present }\end{array}$} \\
\hline \multicolumn{10}{|l|}{$\begin{array}{l}\text { Application decisions are based on } \\
\text { scouting data, pest thresholds and/or } \\
\text { risk assessment models }\end{array}$} \\
\hline \multicolumn{10}{|l|}{$\begin{array}{l}\text { Pesticides are selected for lower risk of } \\
\text { runoff or leaching based upon site } \\
\text { conditions, pesticide label warnings, } \\
\text { or transport models } \\
\text { www.wcc.nrcs.usda.gov/pestmgt/winp } \\
\text { st.html }\end{array}$} \\
\hline \multicolumn{10}{|l|}{ "Hot spots" are treated independently } \\
\hline $\begin{array}{l}\text { Pesticides are applied at the lowest } \\
\text { effective labeled rate }\end{array}$ & & & & & & & & & \\
\hline & & & & & & & & & \\
\hline
\end{tabular}


Site Assessment and Practices Planning-Sediment, cont'd.

\section{Pesticide Handling}

P2. Are pesticides stored on site?

$\square$ Yes $\square$ No

Notes:

P3. Are pesticides mixed and loaded on site?

$\square$ Yes $\square$ No

Notes:

P4. Are pesticides (organic and/or synthetic) applied to crops, including ground applied, foliar applied, and chemigation?

$\square$ Yes $\square$ No

Notes:

\begin{tabular}{|c|c|c|c|c|c|c|c|c|c|}
\hline \multicolumn{10}{|c|}{$\begin{array}{c}\text { Implement Responsible Storage Application } \\
\text { and Disposal Practices }\end{array}$} \\
\hline & \multirow{2}{*}{$\begin{array}{l}\text { Used or } \\
\text { could be } \\
\text { helpful }\end{array}$} & \multirow[b]{2}{*}{ Location(s) } & \multicolumn{7}{|c|}{ Year(s) used } \\
\hline & & & ষ্ণ & 识 & ஜ & i̊ & $\underset{\infty}{\infty}$ & 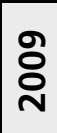 & $\stackrel{\circ}{\stackrel{0}{\circ}}$ \\
\hline \multicolumn{10}{|c|}{ Handle Materials Safely } \\
\hline \multicolumn{10}{|l|}{$\begin{array}{l}\text { Pesticide handlers and applicators } \\
\text { receive yearly training }\end{array}$} \\
\hline \multicolumn{10}{|l|}{$\begin{array}{l}\text { Pesticide label instructions and } \\
\text { environmental hazard warnings are } \\
\text { followed }\end{array}$} \\
\hline \multicolumn{10}{|l|}{$\begin{array}{l}\text { Application equipment and/or } \\
\text { injectors are checked and calibrated } \\
\text { regularly }\end{array}$} \\
\hline \multicolumn{10}{|l|}{$\begin{array}{l}\text { Acreage to be treated and soil types } \\
\text { are known }\end{array}$} \\
\hline \multicolumn{10}{|l|}{$\begin{array}{l}\text { Pesticides sprayers are turned off } \\
\text { when equipment is making turns } \\
\text { outside of rows }\end{array}$} \\
\hline \multicolumn{10}{|l|}{$\begin{array}{l}\text { Pesticides are not sprayed when winds } \\
\text { could move pesticides off-target as } \\
\text { 'drift' }\end{array}$} \\
\hline \multicolumn{10}{|l|}{$\begin{array}{l}\text { Greenhouse exhaust fans are turned } \\
\text { off during applications }\end{array}$} \\
\hline $\begin{array}{l}\text { Rain events are considered - pesticides } \\
\text { are not applied prior to projected rain } \\
\text { events }\end{array}$ & & & & & & & & & \\
\hline
\end{tabular}


Site Assessment and Practices Planning-Sediment, cont'd.

\begin{tabular}{|c|c|c|c|c|c|c|c|c|c|}
\hline & \multirow{2}{*}{$\begin{array}{l}\text { Used or } \\
\text { could be } \\
\text { helpful }\end{array}$} & \multirow[b]{2}{*}{ Location(s) } & \multicolumn{7}{|c|}{ Year(s) used } \\
\hline & & & ষ্ণ & in & ○్̊ㅁ & 용 & 足 & 유 & 응 \\
\hline \multicolumn{10}{|l|}{$\begin{array}{l}\text { Pesticide applications in ditches occur } \\
\text { when water quality impacts are } \\
\text { minimal and materials are used that } \\
\text { are approved for use near aquatic } \\
\text { habitat }\end{array}$} \\
\hline \multicolumn{10}{|l|}{$\begin{array}{l}\text { Disposal methods are environmentally } \\
\text { safe }\end{array}$} \\
\hline \multicolumn{10}{|c|}{ Design Facilities Appropriately } \\
\hline $\begin{array}{l}\text { The pesticide storage facility includes a } \\
\text { concrete pad and curb to contain spills } \\
\text { and leaks }\end{array}$ & & & & & & & & & \\
\hline $\begin{array}{l}\text { Production wells are located on } \\
\text { elevated, impervious bases and are } \\
\text { upslope of pesticide storage and } \\
\text { handling facilities }\end{array}$ & & & & & & & & & \\
\hline $\begin{array}{l}\text { Wellhead protection consists of an } \\
\text { impermeable pad, sump or buffer area } \\
\text { of } 100^{\prime} \text { around the wellhead that } \\
\text { excludes pesticide handling and } \\
\text { pesticide laden drainage }\end{array}$ & & & & & & & & & \\
\hline $\begin{array}{l}\text { Containment basins are lined to } \\
\text { prevent leaching of pesticides }\end{array}$ & & & & & & & & & \\
\hline $\begin{array}{l}\text { Mixing is performed on low runoff } \\
\text { hazard sites - over } 100 \text { feet } \\
\text { downslope of wells on an } \\
\text { impermeable surface }\end{array}$ & & & & & & & & & \\
\hline Agrichemical Handling Facility \# 702 & & & & & & & & & \\
\hline & & & & & & & & & \\
\hline
\end{tabular}


Site Assessment and Practices Planning-Sediment, cont'd.

\section{Reducing Pesticide Movement}

P5. Do the pesticides applied to your crops have the potential to move offsite adsorbed to sediment, in runoff water and/or by leaching?

$\square$ Yes $\square$ No

Notes:

P6. Are you aware of pesticides in the soil from historic applications?

$\square$ Yes $\square$ No

Notes:

Reduce Pesticide Movement with Water and Eroding Soil

Used or could be helpful Year(s) used

Location(s)

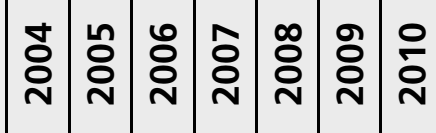

Design Field Layout to Minimize Pesticide Movement

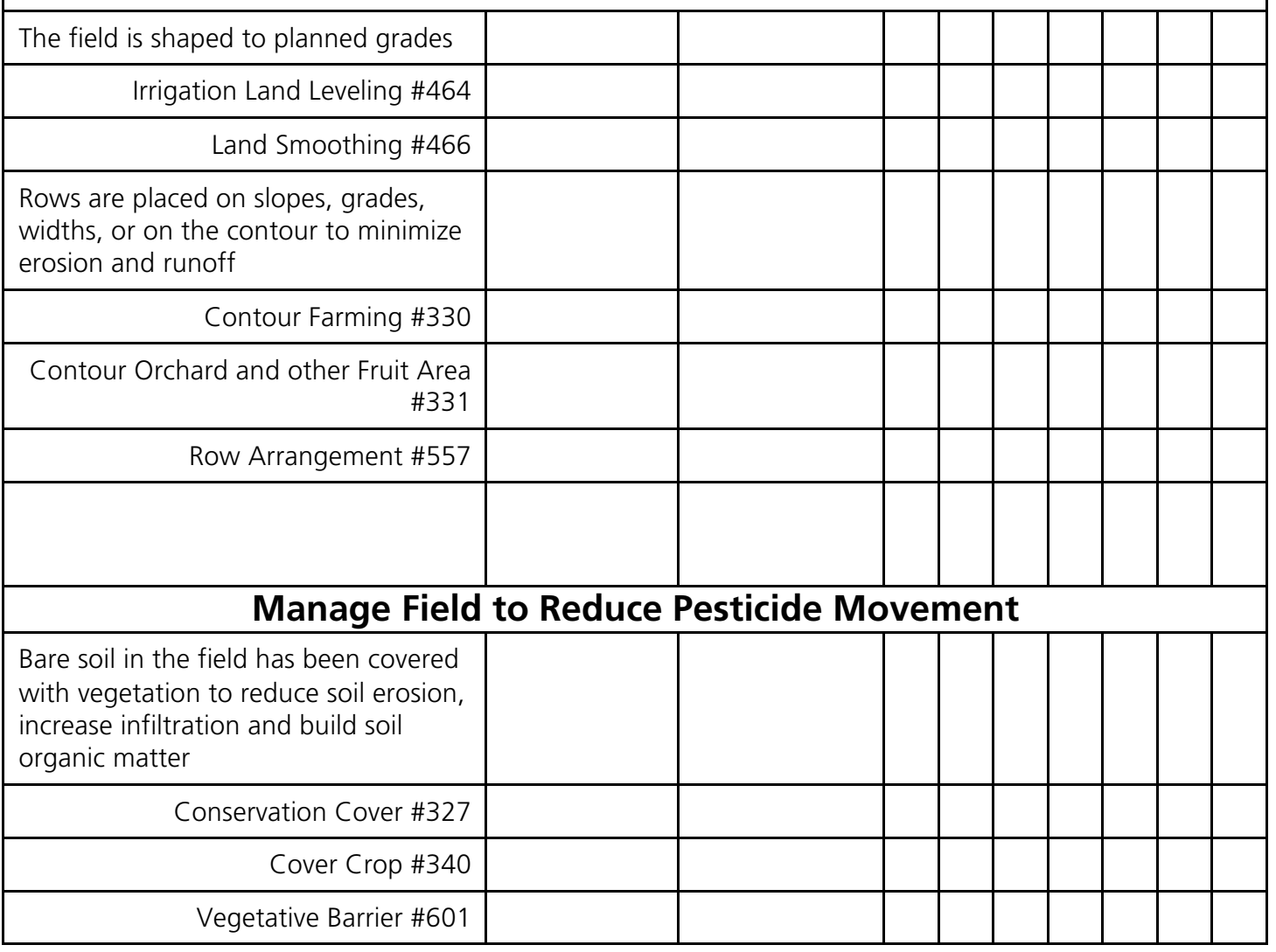


Site Assessment and Practices Planning-Sediment, cont'd.

\begin{tabular}{|c|c|c|c|c|c|c|c|c|c|}
\hline & \multirow{2}{*}{$\begin{array}{l}\text { Used or } \\
\text { could be } \\
\text { helpful }\end{array}$} & \multirow[b]{2}{*}{ Location(s) } & \multicolumn{7}{|c|}{ Year(s) used } \\
\hline & & & 广̊ & in & ஜ & 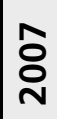 & $\stackrel{\infty}{\circ}$ & 옹 & 웅 \\
\hline \multicolumn{10}{|l|}{$\begin{array}{l}\text { Plant residues are retained or other } \\
\text { materials are applied to the soil or } \\
\text { substrate surface }\end{array}$} \\
\hline \multicolumn{10}{|l|}{ Mulching \#484 } \\
\hline \multicolumn{10}{|l|}{ Residue Management \#329 } \\
\hline \multicolumn{10}{|l|}{$\begin{array}{l}\text { Deep tillage is performed to fracture } \\
\text { restrictive soil layers and increase deep } \\
\text { percolation where leaching of } \\
\text { pollutants to groundwater is not a } \\
\text { significant risk }\end{array}$} \\
\hline \multicolumn{10}{|l|}{ Deep Tillage \#324 } \\
\hline \multicolumn{10}{|l|}{$\begin{array}{l}\text { Irrigations are managed to minimize } \\
\text { leaching and runoff }\end{array}$} \\
\hline \multicolumn{10}{|l|}{ Irrigation Water Management \#449 } \\
\hline \multicolumn{10}{|l|}{$\begin{array}{l}\text { Strips of perennial vegetation are } \\
\text { placed along rows farmed on the } \\
\text { contour }\end{array}$} \\
\hline \multicolumn{10}{|l|}{ Contour Buffer Strip \#332 } \\
\hline \multicolumn{10}{|l|}{$\begin{array}{l}\text { A structure to collect sediment } \\
\text { containing pesticides is installed and } \\
\text { maintained }\end{array}$} \\
\hline \multicolumn{10}{|l|}{ Sediment Basin \#350 } \\
\hline \multicolumn{10}{|l|}{$\begin{array}{r}\text { Water and Sediment Control Basin } \\
\text { \#638 }\end{array}$} \\
\hline \multicolumn{10}{|l|}{$\begin{array}{r}\text { Irrigation System, Tailwater Recovery } \\
\# 447\end{array}$} \\
\hline \multicolumn{10}{|l|}{$\begin{array}{l}\text { Vegetation is established along the } \\
\text { downslope field edge to filter } \\
\text { sediment containing pesticides }\end{array}$} \\
\hline \multicolumn{10}{|l|}{ Conservation Cover \#327 } \\
\hline \multicolumn{10}{|l|}{ Filter Strip \#393 } \\
\hline \multicolumn{10}{|l|}{$\begin{array}{l}\text { A vegetated channel is placed } \\
\text { downslope of the field }\end{array}$} \\
\hline Grassed Waterway \#412 & & & & & & & & & \\
\hline & & & & & & & & & \\
\hline
\end{tabular}


Site Assessment and Practices Planning-Sediment, cont'd.

\section{Managing Nutrients}

Nutrient sources associated with agricultural production practices include fertilizers and other amendments, nutrients in groundwater used in irrigation, biodegradation of crop residues, agricultural and municipal waste applied to land, and waste generated by animals directly. Nutrients from these sources become pollutants when they are transported offsite into nearby streams and lakes or percolate in excessive amounts to groundwater. Nitrates and phosphates in surface water bodies contribute to eutrophication. Eutrophication leads to increases in aquatic plants and algal blooms that deplete dissolved oxygen, impacting aquatic organisms. Nitrate pollution of groundwater is widespread and a serious problem statewide because of impacts to drinking water. Nitrates are watersoluble and have the potential to leach or to run off in surface water. Phosphates attach to soil particles and have the potential to move offsite with eroding soil. In areas with high concentrations of accumulated soil phosphorus, phosphorus can also be carried off as dissolved phosphate in runoff water. Many practices in this section fall under NRCS Conservation Practice Standard Nutrient Management \#590.

\section{Nutrient Management Program}

N1. Do you apply sources of nitrogen (N) and/or phosphorus (P) (fertilizer, compost, manure)?

$\square$ Yes $\square$ No

Notes:

Make Informed Nutrient Management Decisions

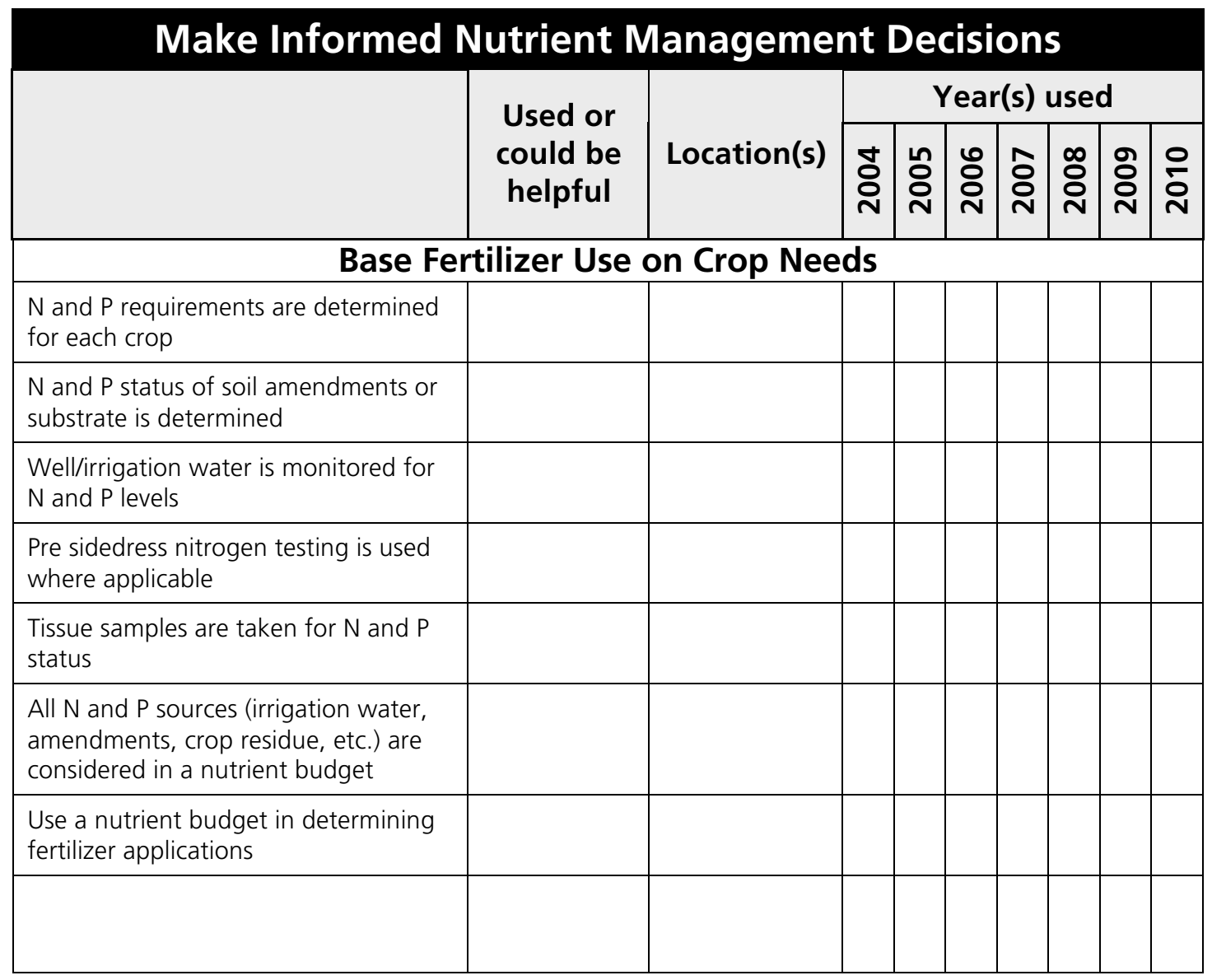


Site Assessment and Practices Planning-Sediment, cont'd.

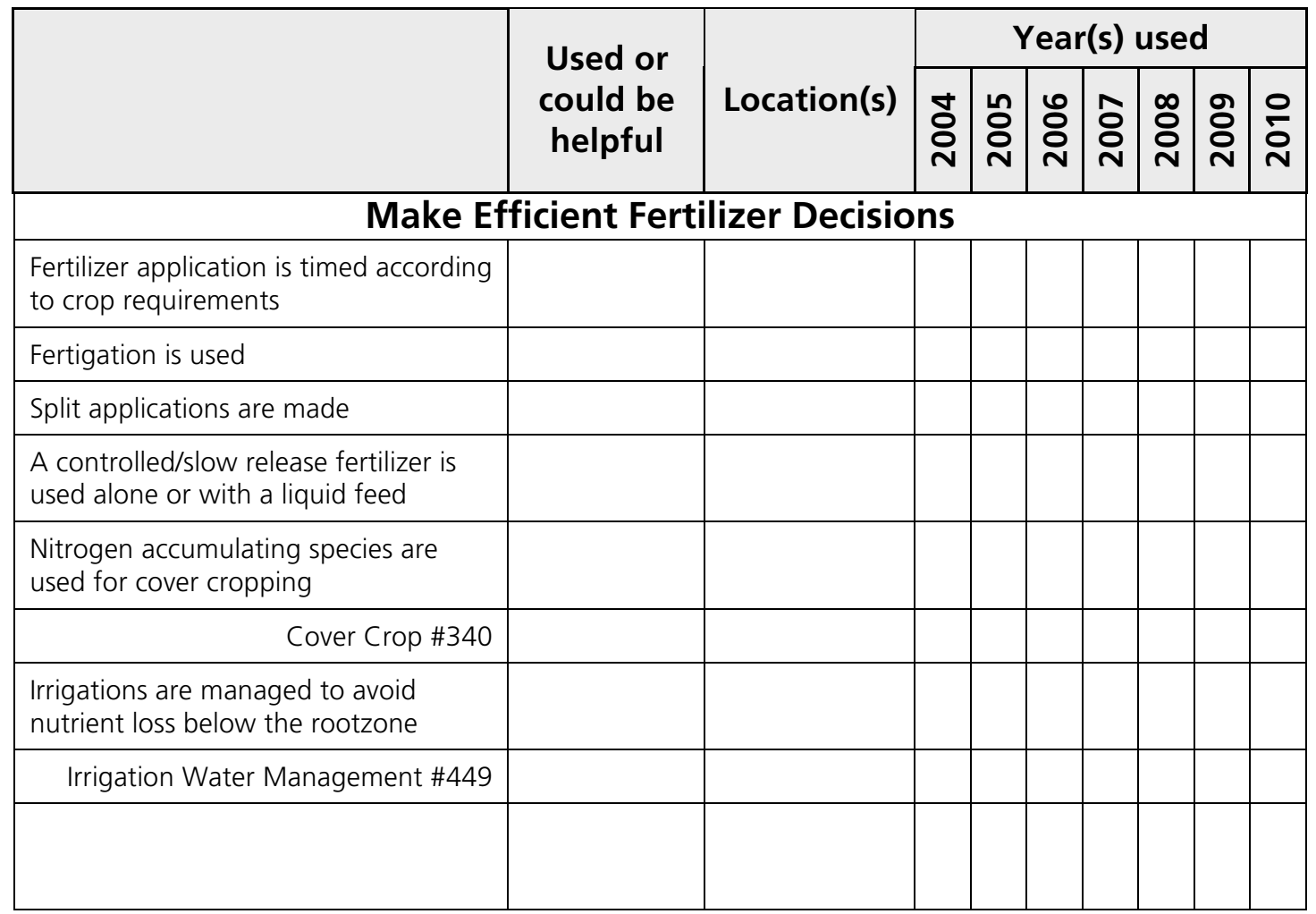


Site Assessment and Practices Planning-Sediment, cont'd.

\section{Nutrient Handling}

N2. Are fertilizers stored and/or mixed on site?

$\square$ Yes $\square$ No

Notes:

N3. Are fertilizers (organic and/or synthetic) applied to crops, including pre-mixing with soil substrates, ground applied, foliar applied, and fertigation?

$\square$ Yes $\square$ No

Notes:

\begin{tabular}{|c|c|c|c|c|c|c|c|c|c|}
\hline \multicolumn{10}{|c|}{$\begin{array}{r}\text { Implement Responsible Storage, A } \\
\text { and Disposal Practices }\end{array}$} \\
\hline & $\begin{array}{l}\text { Used or } \\
\text { could be } \\
\text { helpful }\end{array}$ & Location(s) & 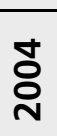 & $\stackrel{\text { ก }}{\text { ก }}$ & ○ீ & 옹 & $\stackrel{\infty}{\stackrel{0}{\circ}}$ & $\stackrel{\text { ̊ }}{\circ}$ & 응 \\
\hline \multicolumn{10}{|c|}{ Handle Materials Safely } \\
\hline \multicolumn{10}{|c|}{\begin{tabular}{l|l|l} 
Application equipment and/or & & \\
injectors are checked and calibrated & & \\
regularly & & \\
\end{tabular}} \\
\hline \multicolumn{10}{|l|}{$\begin{array}{l}\text { Precision placement is used to apply } \\
\text { fertilizer close to roots }\end{array}$} \\
\hline \multicolumn{10}{|l|}{$\begin{array}{l}\text { Fertilizer handlers and applicators } \\
\text { receive training }\end{array}$} \\
\hline \multicolumn{10}{|l|}{$\begin{array}{l}\text { Rain and irrigation events are } \\
\text { considered - Fertilizers are not applied } \\
\text { prior to projected rain events or } \\
\text { irrigations }\end{array}$} \\
\hline \multicolumn{10}{|c|}{ Design Facilities Appropriately } \\
\hline \multicolumn{10}{|c|}{ 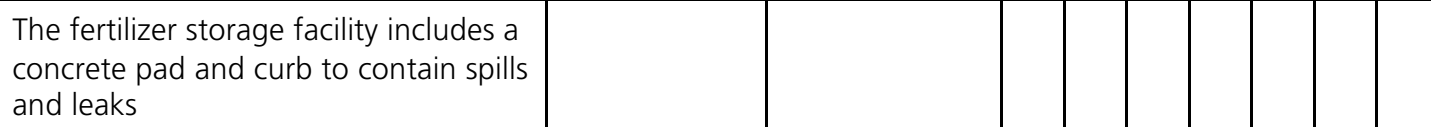 } \\
\hline \multicolumn{10}{|l|}{$\begin{array}{l}\text { Mixing is performed on low runoff } \\
\text { hazard sites - over } 100 \text { feet } \\
\text { downslope of the well on an } \\
\text { impermeable surface }\end{array}$} \\
\hline \multicolumn{10}{|l|}{ Agrichemical Handling Facility \#702 } \\
\hline & & & & & & & & & \\
\hline
\end{tabular}


Site Assessment and Practices Planning-Sediment, cont'd.

\section{Reducing Nutrient Movement}

N4. Does the fertilizer applied to your crops have the potential to move offsite attached to sediment, in runoff water or by leaching?

$\square$ Yes $\square$ No

Notes:

\section{Reduce Nutrient Movement with Water and Eroding Soil}

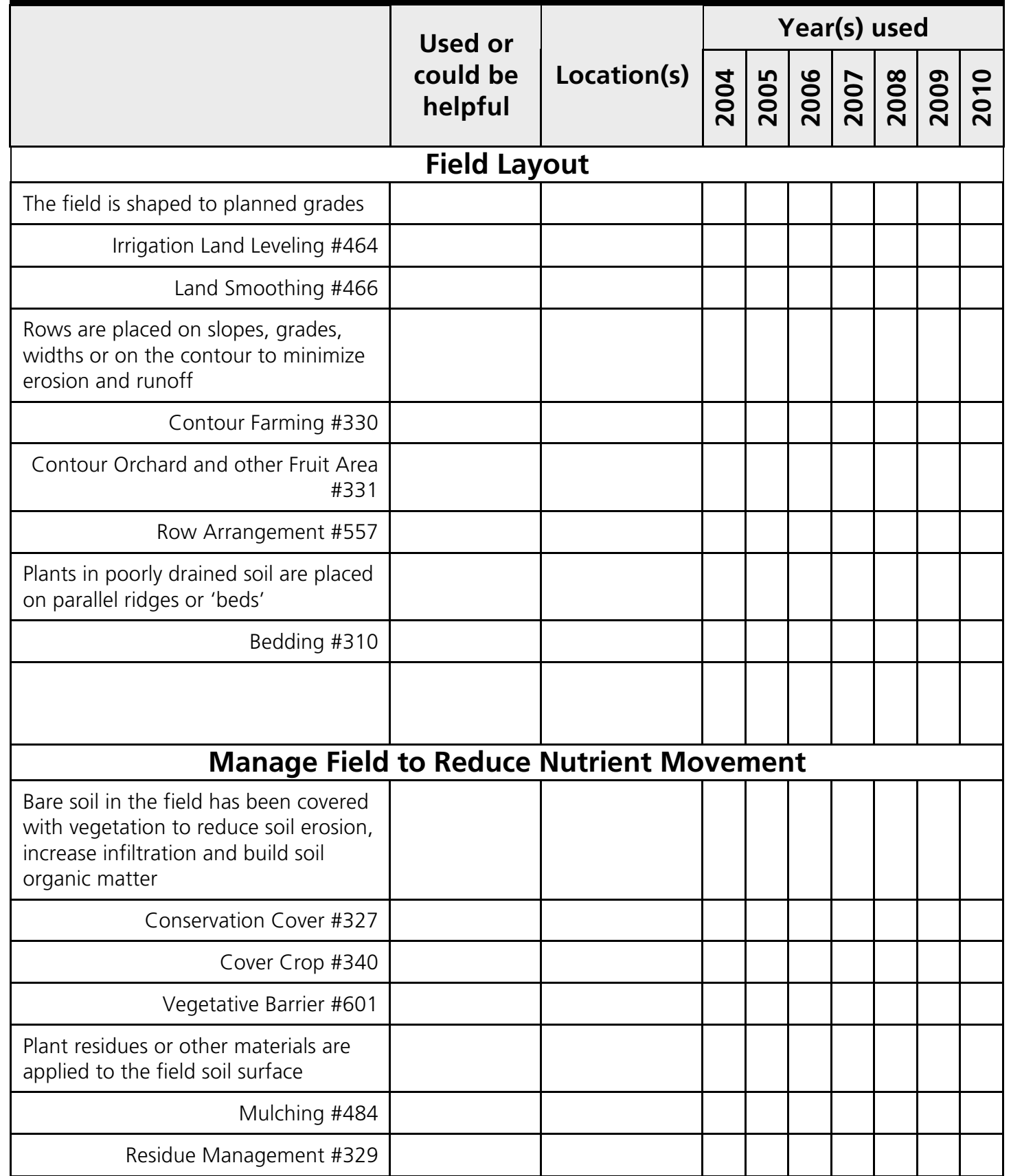


Site Assessment and Practices Planning-Sediment, cont'd.

\begin{tabular}{|c|c|c|c|c|c|c|c|c|c|}
\hline & \multirow{2}{*}{$\begin{array}{l}\text { Used or } \\
\text { could be } \\
\text { helpful }\end{array}$} & \multirow[b]{2}{*}{ Location(s) } & \multicolumn{7}{|c|}{ Year(s) used } \\
\hline & & & ষ্ণ & 옹 & ర̊̊ & 용 & $\stackrel{\infty}{\circ}$ & 옹 & 응 \\
\hline $\begin{array}{l}\text { Deep tillage is performed to fracture } \\
\text { restrictive soil layers and increase deep } \\
\text { percolation where leaching of } \\
\text { pollutants to groundwater is not a } \\
\text { significant risk }\end{array}$ & & & & & & & & & \\
\hline \multicolumn{10}{|l|}{ Deep Tillage \#324 } \\
\hline \multicolumn{10}{|l|}{$\begin{array}{l}\text { Irrigations are managed to minimize } \\
\text { leaching and runoff }\end{array}$} \\
\hline \multicolumn{10}{|l|}{ Irrigation Water Management \#449 } \\
\hline \multicolumn{10}{|l|}{$\begin{array}{l}\text { Strips of perennial vegetation are } \\
\text { placed along rows farmed on the } \\
\text { contour }\end{array}$} \\
\hline \multicolumn{10}{|l|}{ Contour Buffer Strip \#332 } \\
\hline \multicolumn{10}{|l|}{$\begin{array}{l}\text { A structure to collect sediment } \\
\text { containing nutrients is installed and } \\
\text { maintained }\end{array}$} \\
\hline \multicolumn{10}{|l|}{$\begin{array}{r}\text { Irrigation System, Tailwater Recovery } \\
\# 447\end{array}$} \\
\hline \multicolumn{10}{|l|}{ Sediment Basin \#350 } \\
\hline \multicolumn{10}{|l|}{$\begin{array}{r}\text { Water and Sediment Control Basin } \\
\# 638\end{array}$} \\
\hline \multicolumn{10}{|l|}{$\begin{array}{l}\text { Vegetation is established along the } \\
\text { downslope field edge to filter } \\
\text { sediment containing nutrients }\end{array}$} \\
\hline \multicolumn{10}{|l|}{ Conservation Cover \#327 } \\
\hline \multicolumn{10}{|l|}{ Filter Strip \#393 } \\
\hline \multicolumn{10}{|l|}{$\begin{array}{l}\text { Vegetation is placed downslope of the } \\
\text { field }\end{array}$} \\
\hline \multicolumn{10}{|l|}{ Grassed Waterway \#412 } \\
\hline Constructed Wetland \#656 & & & & & & & & & \\
\hline & & & & & & & & & \\
\hline
\end{tabular}


Site Assessment and Practices Planning-Sediment, cont'd.

\section{Nutrient Waste}

N5. Is there a septic system on the farm or operation?

$\square$ Yes $\square$ No

Notes:

N6. Do livestock have access to a waterbody?

$\square$ Yes $\square$ No

Notes:

N7. Is there a feedlot, loafing area, or concentration of livestock near a waterbody?

$\square$ Yes $\square$ No

Notes:

\section{Reduce Nutrient Pollution from Human} and/or Livestock Waste

\begin{tabular}{|c|c|c|c|c|c|c|c|c|c|}
\hline & \multirow{2}{*}{$\begin{array}{l}\text { Used or } \\
\text { could be } \\
\text { helpful }\end{array}$} & \multirow[b]{2}{*}{ Location(s) } & \multicolumn{7}{|c|}{ Year(s) used } \\
\hline & & & ঠ্ণ & 옹 & ஜ & ᄋ̊ & $\begin{array}{l}\infty \\
\stackrel{0}{0} \\
\stackrel{N}{N}\end{array}$ & 옹 & 응 \\
\hline \multicolumn{10}{|l|}{$\begin{array}{l}\text { Septic systems are inspected and } \\
\text { maintained }\end{array}$} \\
\hline \multicolumn{10}{|l|}{$\begin{array}{l}\text { Portable toilets are regularly } \\
\text { maintained to avoid spills }\end{array}$} \\
\hline \multicolumn{10}{|l|}{$\begin{array}{l}\text { Livestock are fenced off from } \\
\text { waterways }\end{array}$} \\
\hline \multicolumn{10}{|l|}{ Fence \#382 } \\
\hline \multicolumn{10}{|l|}{ Use Exclusion \#472 } \\
\hline \multicolumn{10}{|l|}{$\begin{array}{l}\text { Livestock are directed away from } \\
\text { waterbodies with placement of } \\
\text { troughs, salt licks, dusters and/or trails. }\end{array}$} \\
\hline \multicolumn{10}{|l|}{ Animal Trails or Walkways \#575 } \\
\hline \multicolumn{10}{|l|}{ Prescribed Grazing \#528 } \\
\hline Watering Facility \#614 & & & & & & & & & \\
\hline & & & & & & & & & \\
\hline
\end{tabular}


Site Assessment and Practices Planning-Sediment, cont'd.

\section{Managing Salinity}

Irrigation water is essential for crop production in the arid and semiarid regions of California. Irrigation water naturally contains a certain amount of dissolved minerals (salts) depending on its source. Typical irrigation water contains a substantial amount of salt. For example a water source with an EC of 1.0 $\mathrm{mmho} / \mathrm{cm}$, a quality suitable for irrigation of most crops, contains nearly a ton of salt in every ac-foot of water applied. In some coastal areas, increased groundwater pumping has resulted in salt water intrusion from the ocean, threatening the overall groundwater quality. In areas such as the Salinas Basin, surface water quality degradation of ponds and sloughs has resulted from high salt levels in irrigation return flow.

\section{Salinity Management Program}

1. Is salt accumulation from irrigation, fertilizer, and/or amendments a potential problem?

$\square$ Yes $\square$ No

Notes:

\section{Manage Soil Salinity}

Used or could be helpful Location(s)

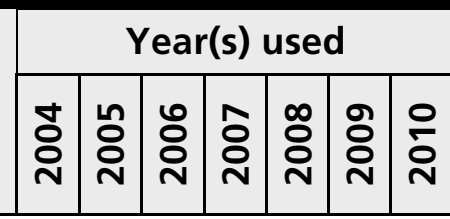

Manage Salinity from Irrigation Water

The salinity of irrigation water is evaluated

The distribution uniformity of the irrigation system is improved or maintained

Appropriate leaching fractions are used

Fields are graded to improve irrigation uniformity

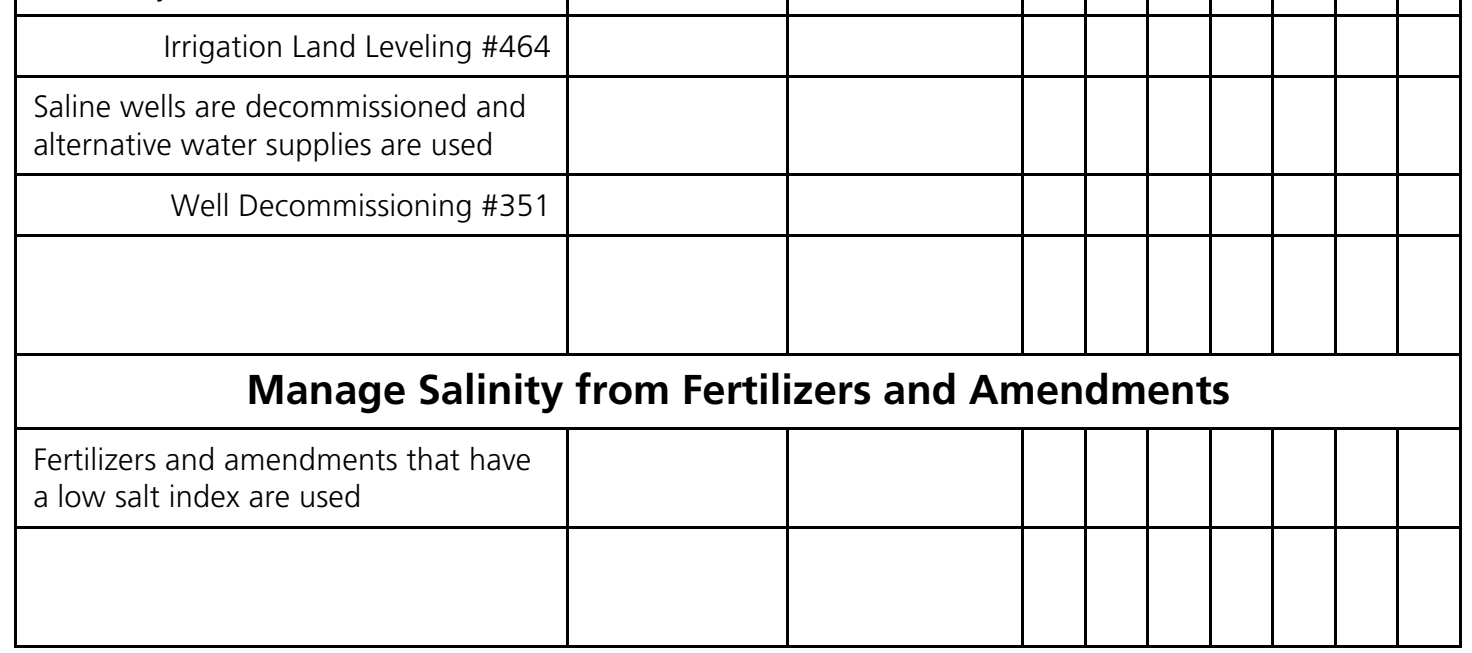


Site Assessment and Practices Planning-Sediment, cont'd.

\begin{tabular}{|c|c|c|c|c|c|c|c|c|c|}
\hline & \multirow{2}{*}{$\begin{array}{l}\text { Used or } \\
\text { could be } \\
\text { helpful }\end{array}$} & \multirow[b]{2}{*}{ Location(s) } & \multicolumn{7}{|c|}{ Year(s) used } \\
\hline & & & 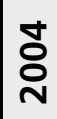 & 号 & ○̊ & ᄋ̊ & 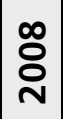 & @ & 웅 \\
\hline \multicolumn{10}{|c|}{ Manage Saline Soils } \\
\hline \multicolumn{10}{|l|}{ Soil salinity is evaluated } \\
\hline \multicolumn{10}{|l|}{$\begin{array}{l}\text { Gypsum and other calcium containing } \\
\text { amendments to reduce the build-up of } \\
\text { exchangeable sodium (ESP) are used }\end{array}$} \\
\hline \multicolumn{10}{|l|}{$\begin{array}{l}\text { Sulfur amendments are used to reduce } \\
\text { soil pH }\end{array}$} \\
\hline \multicolumn{10}{|l|}{$\begin{array}{l}\text { Where leaching of pollutants to } \\
\text { groundwater is not a significant risk, } \\
\text { deep tillage is used to break-up } \\
\text { hardpan layers that prevent salts from } \\
\text { leaching }\end{array}$} \\
\hline \multicolumn{10}{|l|}{ Deep Tillage \#324 } \\
\hline \multicolumn{10}{|l|}{$\begin{array}{l}\text { A tile drain system is used to improve } \\
\text { drainage }\end{array}$} \\
\hline \multicolumn{10}{|l|}{ Subsurface Drain \#606 } \\
\hline \multicolumn{10}{|l|}{$\begin{array}{l}\text { Cover crops are used to improve water } \\
\text { infiltration into soil }\end{array}$} \\
\hline \multicolumn{10}{|l|}{ Cover Crop \#340 } \\
\hline \multicolumn{10}{|l|}{$\begin{array}{l}\text { Amendments are used to improve } \\
\text { infiltration (PAM, gypsum, organic } \\
\text { amendments) }\end{array}$} \\
\hline \multicolumn{10}{|l|}{ Anionic Polyacrylamide (PAM) \#450 } \\
\hline & & & & & & & & & \\
\hline
\end{tabular}


Site Assessment and Practices Planning-Sediment, cont'd.

\section{Practices to Improve Water Quality in Waterways}

Waterways, streams, and riparian areas are sensitive to damage from agricultural, forest and other land use activities and practices. Healthy riparian areas protect farmland from erosion and flooding. They also buffer waterways from the effects of potential nutrient and pesticide runoff.

\section{Land Management Impacts on Waterways}

W1. Is there the potential for soil to fall into the waterway or riparian area from cultural operations along the banks (disking, road grading, etc...)?

$\square$ Yes $\square$ No

Notes:

W2. Are there cattle trails along the waterway and/or do cattle graze in the waterway? $\square$ Yes $\square$ No

Notes:

W3. Do you see mud or sediment filling the waterway?

$\square$ Yes $\square$ No

Notes:

\section{Protect Waterbodies and Riparian Areas}

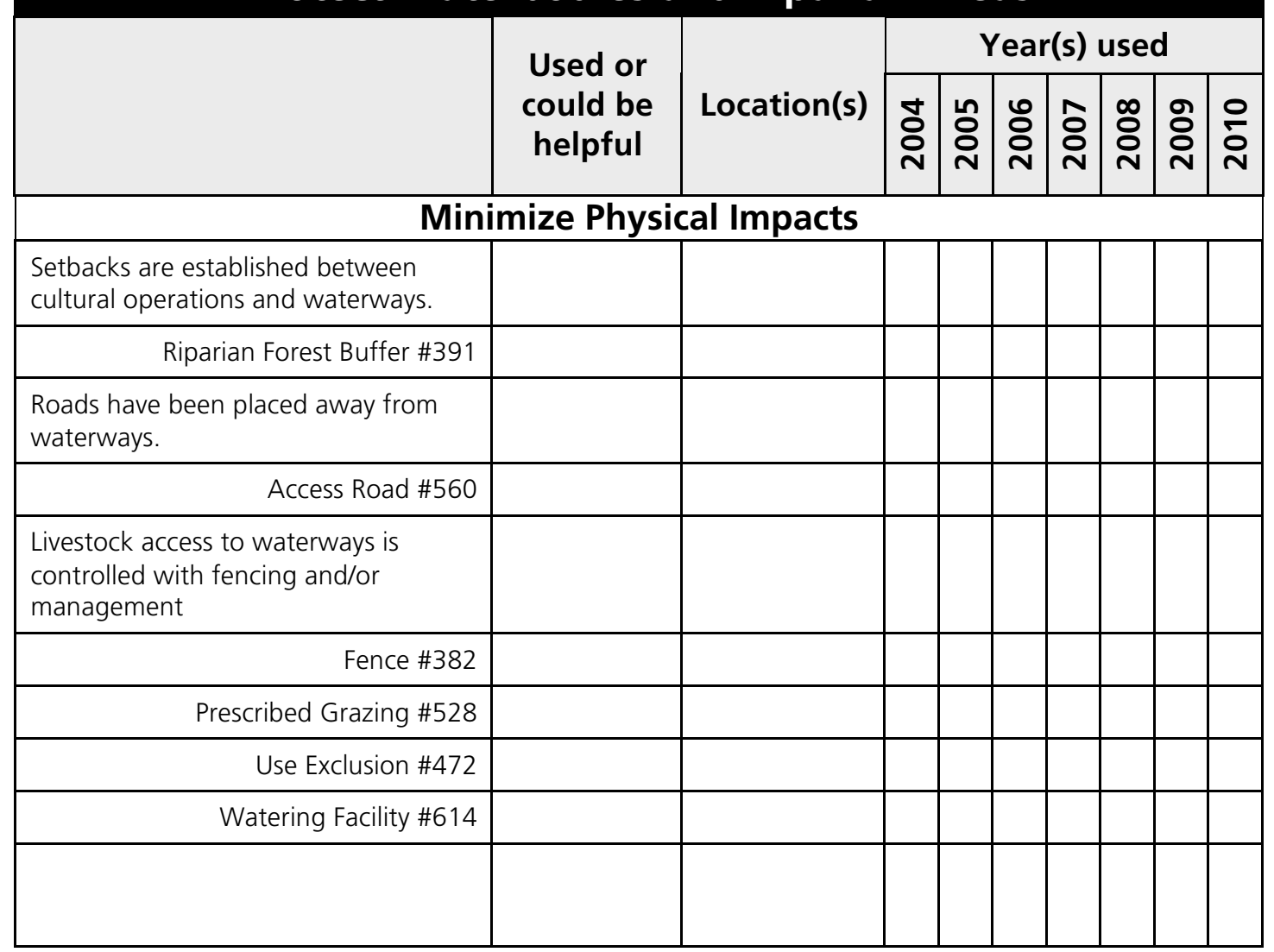


Site Assessment and Practices Planning-Sediment, cont'd.

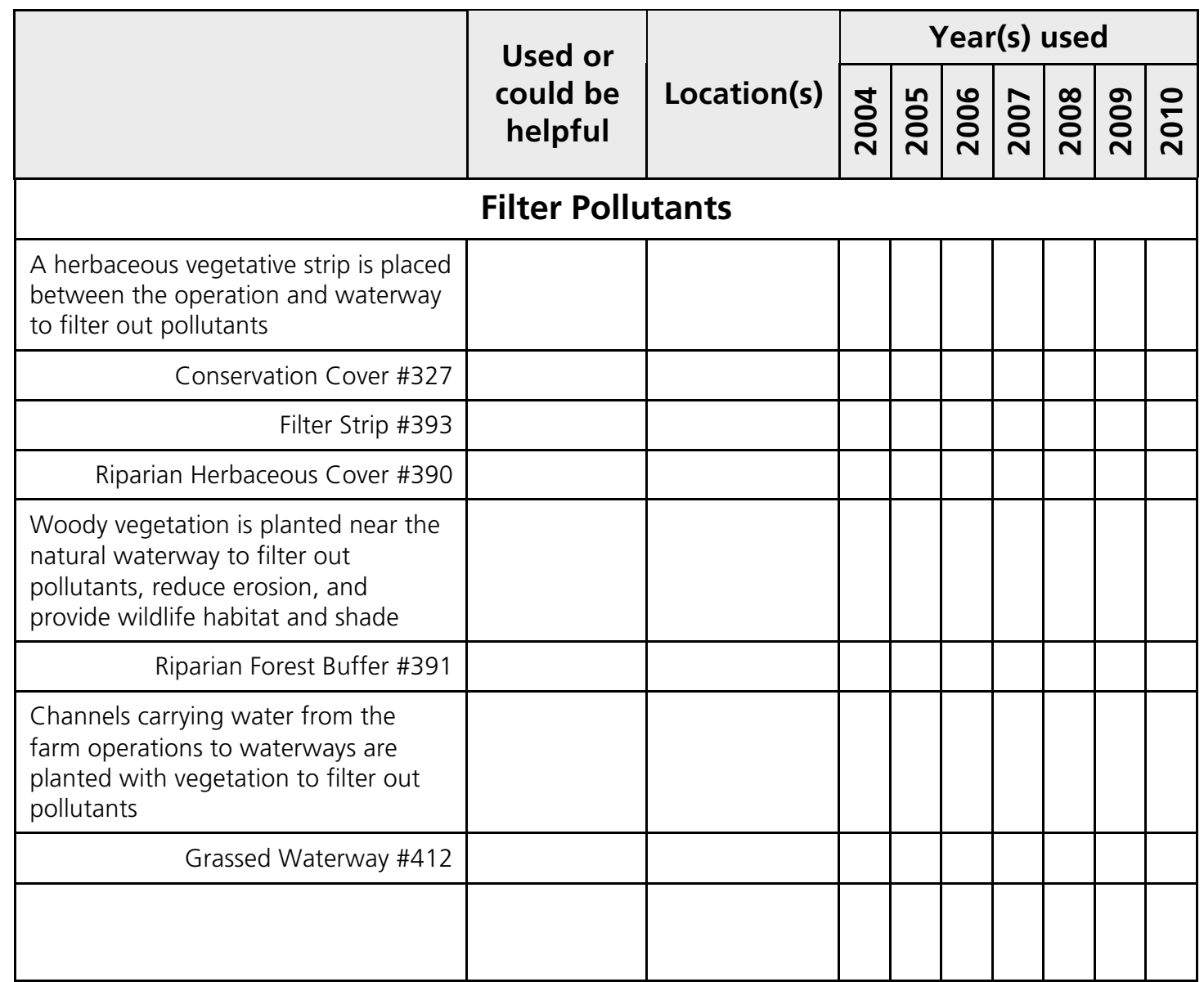


Site Assessment and Practices Planning-Sediment, cont'd.

\section{Waterway Bank and Channel Management}

W4. Is there bare soil along banks and/or are there bank sections that are unstable (i.e. vertical banks) due to inadequate vegetation?

$\square$ Yes $\square$ No

Notes:

W5. Do you notice the waterway depth is eroding or downcutting?

$\square$ Yes $\square$ No

Notes:

W6. Do you notice bank erosion caused by the impacts of bank armoring?

$\square$ Yes $\square$ No

Notes:

W7. Does concentrated runoff entering the waterway result in bank erosion or gullies?

$\square$ Yes $\square$ No

Notes:

\begin{tabular}{|c|c|c|c|c|c|c|c|c|c|}
\hline & \multirow{2}{*}{$\begin{array}{l}\text { Used or } \\
\text { could be } \\
\text { helpful }\end{array}$} & \multirow[b]{2}{*}{ Location(s) } & \multicolumn{7}{|c|}{ Year(s) used } \\
\hline & & & ঠ & @̊ & ஜ̊ & ᄋ̊ & $\stackrel{\infty}{\stackrel{\rho}{\ell}}$ & ஜ & $\stackrel{\circ}{\circ}$ \\
\hline $\begin{array}{l}\text { Vegetative cover is established on the } \\
\text { banks to reduce erosion and enhance } \\
\text { habitat }\end{array}$ & & & & & & & & & \\
\hline \multicolumn{10}{|l|}{ Channel Bank Vegetation \#322 } \\
\hline \multicolumn{10}{|l|}{ Critical Area Planting \#342 } \\
\hline \multicolumn{10}{|l|}{ Streambank Protection \#580 } \\
\hline \multicolumn{10}{|l|}{$\begin{array}{l}\text { Obstructions in the waterway are } \\
\text { removed to improve water flow and } \\
\text { prevent bank erosion }\end{array}$} \\
\hline \multicolumn{10}{|l|}{ Clearing and Snagging \#326 } \\
\hline \multicolumn{10}{|l|}{$\begin{array}{l}\text { The channel bed is stabilized to } \\
\text { prevent erosion }\end{array}$} \\
\hline \multicolumn{10}{|l|}{ Grade Stabilization Structure \#410 } \\
\hline Stream Channel Stabilization \#584 & & & & & & & & & \\
\hline
\end{tabular}


Site Assessment and Practices Planning-Sediment, cont'd.

\begin{tabular}{|c|c|c|c|c|c|c|c|c|c|}
\hline & \multirow{2}{*}{$\begin{array}{l}\text { Used or } \\
\text { could be } \\
\text { helpful }\end{array}$} & \multirow[b]{2}{*}{ Location(s) } & \multicolumn{7}{|c|}{ Year(s) used } \\
\hline & & & ষ্ণ & in & ○্ํ & 용 & 号 & 유 & $\frac{0}{0}$ \\
\hline \multicolumn{10}{|l|}{$\begin{array}{l}\text { Structures to convey field drainage } \\
\text { water into waterways are installed and } \\
\text { maintained }\end{array}$} \\
\hline \multicolumn{10}{|l|}{ Diversion \#362 } \\
\hline \multicolumn{10}{|l|}{ Grade Stabilization Structure \#410 } \\
\hline \multicolumn{10}{|l|}{ Structure for Water Control \#587 } \\
\hline Underground Outlet \#620 & & & & & & & & & \\
\hline & & & & & & & & & \\
\hline
\end{tabular}


Site Assessment and Practices Planning-Sediment, cont'd.

\section{Waterway Crossings}

W7. Is the waterway crossing prone to washing out?

$\square$ Yes $\square$ No

Notes:

W8. Do you notice channel or bank erosion caused by the impacts of structures such as bridges or crossings?

$\square$ Yes $\square$ No

Notes:

W9. Do your culverts have problems with debris buildup or sediment accumulation?

$\square$ Yes $\square$ No

Notes:

W10. Do you notice water collecting upstream from culvert inlets during storms?

$\square$ Yes $\square$ No

Notes:

W11. Do you see sediment deposited from pooled water above the culvert inlet?

$\square$ Yes $\square$ No

Notes:

W12. Do you see debris deposited upstream of the culvert inlet?

$\square$ Yes $\square$ No

Notes:

W13. Are there high rust lines in any of the metal culvert pipes (this may indicate undersized pipe)? $\square$ Yes $\square$ No

Notes:

W14. Are any culvert inlet or outlets crushed, torn, jagged or with worn through bases?

$\square$ Yes $\square$ No

Notes:

W15. Is there the potential for water to run down the road when the culvert plugs?

$\square$ Yes $\square$ No

Notes: 
Site Assessment and Practices Planning-Sediment, cont'd.

W16. Is the water that comes out of the culvert undercutting the road banik or scouring the channel downstream?

$\square$ Yes $\square$ No

Notes:

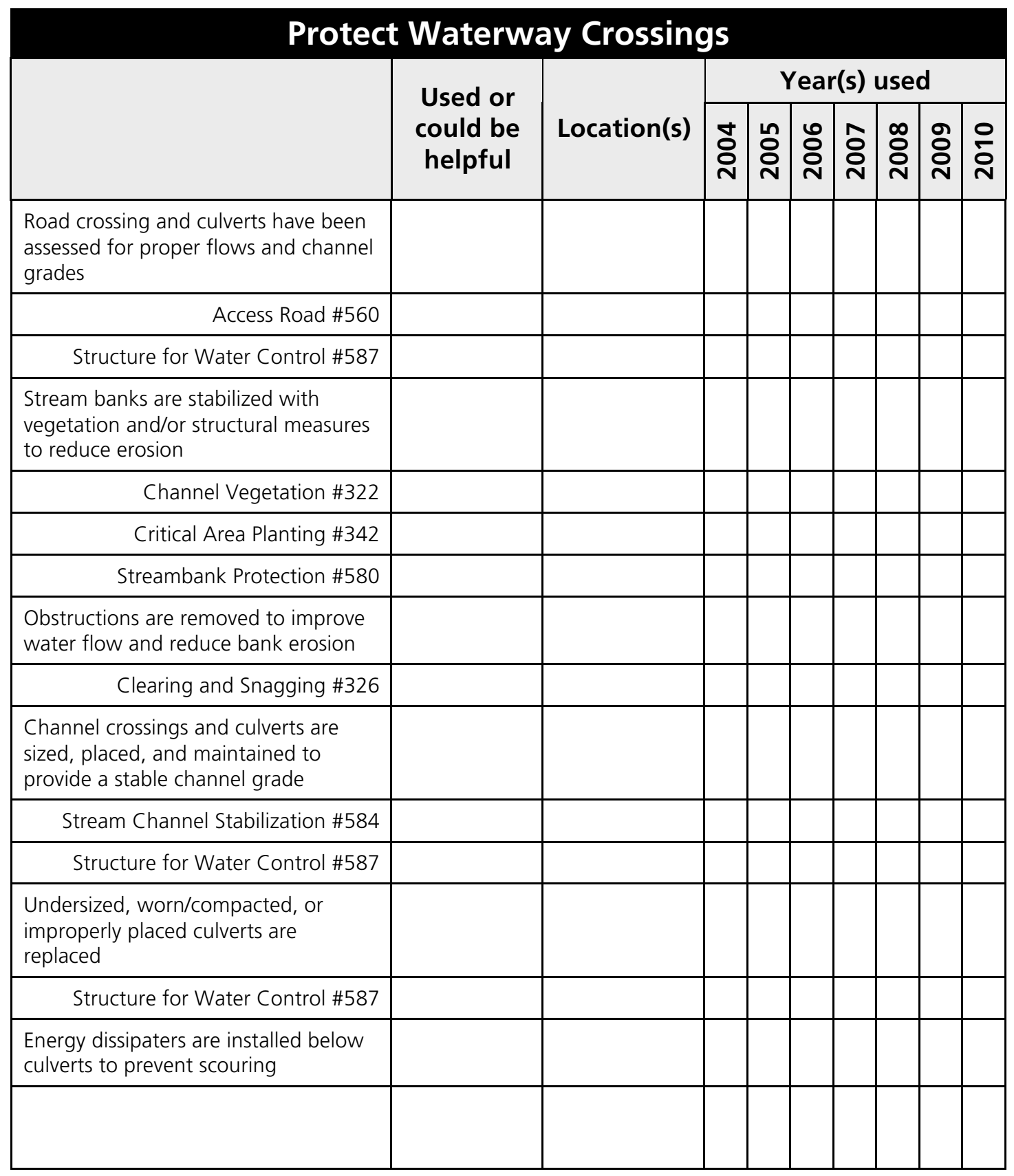


Site Assessment and Practices Planning-Sediment, cont'd.

\section{Stream Habitat}

W12. Are sections of streamflow exposed to sun for more than half the day?

$\square$ Yes $\square$ No

Notes:

W13. Are there potential impediments to fish passage in the stream?

$\square$ Yes $\square$ No

Notes:

W14. Do you notice the encroachment of non-native invasive plant species and/or the loss of native riparian or wetland habitat?

$\square$ Yes $\square$ No

Notes:

\section{Maintain or Improve Stream Habitat}

\begin{tabular}{|c|c|c|c|c|c|c|c|c|c|}
\hline & \multirow{2}{*}{$\begin{array}{l}\text { Used or } \\
\text { could be } \\
\text { helpful }\end{array}$} & \multirow[b]{2}{*}{ Location(s) } & \multicolumn{7}{|c|}{ Year(s) used } \\
\hline & & & ষ্̊ & 웅 & $\begin{array}{l}0 \\
\text { గ̊ }\end{array}$ & 웅 & $\stackrel{\infty}{\infty}$ & 용 & $\stackrel{\circ}{\stackrel{0}{ }}$ \\
\hline \multicolumn{10}{|l|}{$\begin{array}{l}\text { Vegetative cover is established along } \\
\text { banks to reduce erosion and enhance } \\
\text { habitat }\end{array}$} \\
\hline \multicolumn{10}{|l|}{ Channel Bank Vegetation \#322 } \\
\hline \multicolumn{10}{|l|}{ Riparian Forest Buffer \#391 } \\
\hline \multicolumn{10}{|l|}{ Riparian Herbaceous Cover \#390 } \\
\hline \multicolumn{10}{|l|}{ Tree/Shrub Establishment \#612 } \\
\hline \multicolumn{10}{|l|}{$\begin{array}{r}\text { Wetland Wildlife Habitat Management } \\
\# 644\end{array}$} \\
\hline \multicolumn{10}{|l|}{$\begin{array}{l}\text { Invasive plant species are identified, } \\
\text { removed and replaced with native } \\
\text { species }\end{array}$} \\
\hline \multicolumn{10}{|l|}{$\begin{array}{r}\text { Restoration and Management of } \\
\text { Declining Habitats \#643 }\end{array}$} \\
\hline \multicolumn{10}{|l|}{$\begin{array}{l}\text { Stream conditions are improved for } \\
\text { aquatic species }\end{array}$} \\
\hline \multicolumn{10}{|l|}{ Irrigation Storage Reservoir \#436 } \\
\hline \multicolumn{10}{|l|}{ Obstruction Removal \#500 } \\
\hline \multicolumn{10}{|l|}{$\begin{array}{l}\text { Barriers that restrict or prevent fish } \\
\text { migration are removed }\end{array}$} \\
\hline Fish Passage \#396 & & & & & & & & & \\
\hline & & & & & & & & & \\
\hline
\end{tabular}




\section{SELF-EVALUATION}

An essential element of a water quality site self-assessment is the tracking of land use and management activities on your agricultural operation. Self-evaluation data that you can provide can be important in explaining any water quality changes that may occur due to implementation of management practices. Selfevaluation techniques can help determine whether water quality changes can be attributed to implementing management practices and not to other confounding influences such as regional geology or a source upstream of the operation.

Simple field measurements are often undervalued and suspected of lacking scientific validity. When properly designed and carefully executed, however, they can provide sound data. Their strength lies in the possibility of taking large numbers of measurements inexpensively and with only semi-skilled assistance to obtain results that are more pertinent to your site than sophisticated measurements taking place at some distant monitoring station.

Do you keep a record of:

\section{Record Keeping Keep with Plan for reference}

weather conditions such as air temperature, precipitation, and evapotranspiration extreme weather events such as severe storms, floods, and droughts natural vegetation and/or wildlife observations grazing (animal numbers, in and out pasture dates) natural vegetation and/or wildlife observations

\begin{tabular}{|c|c|c|}
\hline \multicolumn{3}{|c|}{$\begin{array}{l}\text { Photo Point Self-Evaluation } \\
\text { Keep photos and historic records with Plan for reference }\end{array}$} \\
\hline \multicolumn{3}{|c|}{$\begin{array}{l}\text { Do you have any historic records and/or photographs that can help you document short or long } \\
\text { term changes on the farm/ranch? Yes No }\end{array}$} \\
\hline \multicolumn{3}{|l|}{ How many photo points are on your farm/ranch? } \\
\hline \multicolumn{3}{|c|}{ How many times per year will photographs be taken? } \\
\hline \multicolumn{3}{|c|}{$\begin{array}{c}\text { Other Self-Evaluation Techniques You Perform or Plan to } \\
\text { Perform } \\
\text { Keep with Plan for reference }\end{array}$} \\
\hline Technique & Location(s) & $\begin{array}{l}\text { Dates or } \\
\text { Schedule }\end{array}$ \\
\hline \multicolumn{3}{|c|}{ Sediments } \\
\hline \multicolumn{3}{|l|}{ Erosion Pins } \\
\hline \multicolumn{3}{|l|}{ Erosion Pipes } \\
\hline \multicolumn{3}{|l|}{ Estimating Streambank Loss } \\
\hline \multicolumn{3}{|l|}{ Imhoff Cones } \\
\hline \multicolumn{3}{|l|}{ Paint Collars } \\
\hline \multicolumn{3}{|l|}{$\begin{array}{l}\text { Sediment Basin or Sand Trap - } \\
\text { (record amount of sediment removed) }\end{array}$} \\
\hline \multicolumn{3}{|l|}{ Staking Gullies or Streambanks } \\
\hline Walking the Runoff & & \\
\hline & & \\
\hline
\end{tabular}


Self-Evaluation, cont'd.

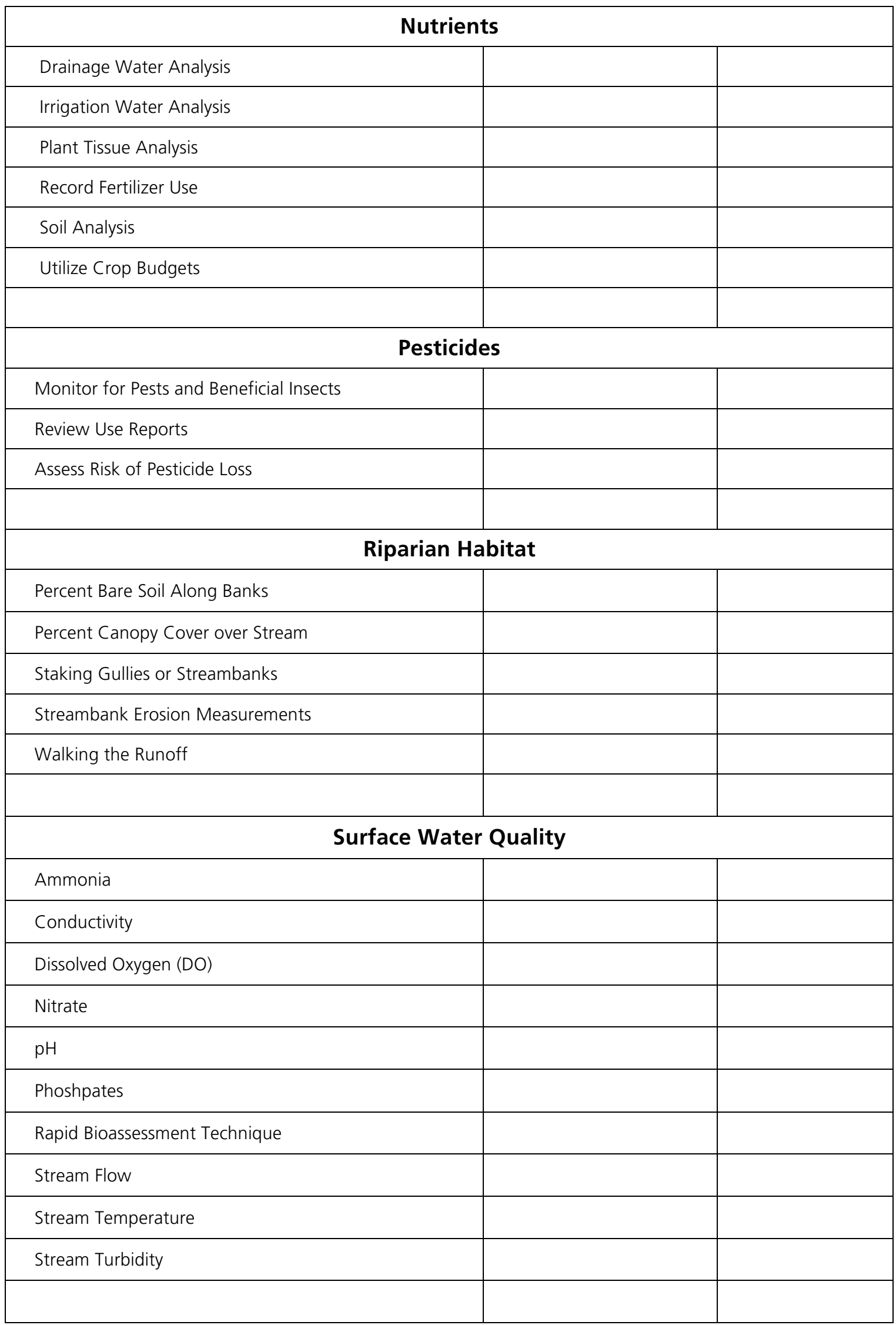


Self-Evaluation, cont'd.

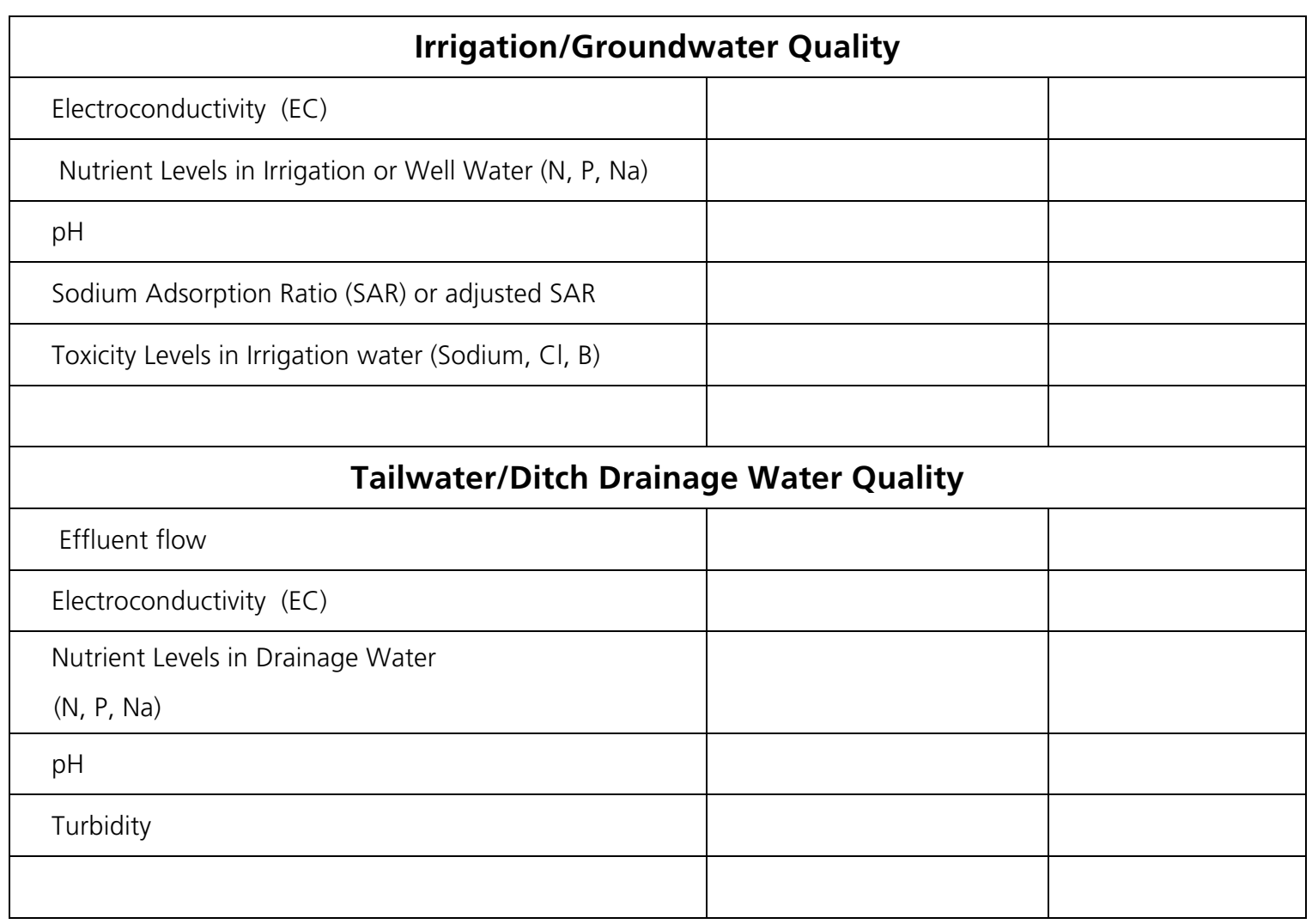




\section{REFERENCES}

Much of the information in the Farm Water Quality Plan has been adapted from the Ranch Water Quality Management Plan created by University of California Cooperative Extension and the USDA Natural Resources Conservation Service (unpublished).

Some practices in the Site Assessment and Practices Planning section were adapted from Production guide: Nitrogen and water management for coastal cool-season vegetables. 1998. G. S. Pettygrove, et al., Division of Agriculture and Natural Resources, University of California, Oakland CA; Farm-A-Syst farmstead assessment system, University of Wisconsin-Extension http://www.uwex.edu/farmasyst; and The Positive Points System, Central Coast Vineyard Team http://www.vineyardteam.org/pps/index.htm.

Numbered practices in the Site Assessment and Practices Planning section refer to USDA-NRCS National handbook of conservation standards. Individual practices can be found at http://www.ftw.nrcs.usda.gov/nhcp_2.html.

Site Assessment and Practices Planning questions E7 through E11 adapted from Downie, Scott, Dennis Halligan and Ross Taylor. 1998. Watershed processes and erosion control: A workbook and compendium. Fish, Farm, and Forest Communities Forum.

\section{ACKN OWLEDGMENTS}

The editors and workgroup wish to acknowledge Julie Fallon, Farm Water Quality Project Program Representative, for her commitment, creativity, and tenacity in the development of the Farm Water Quality curriculum and in particular the Template Farm Water Quality Plan. Julie guided every publication in the curriculum from peer review to publication while incorporating input form researchers, technical staff, and growers. Our thanks and appreciation to her for her work.

\section{NPS Pollutant Information Collaborators}

The following provided technical information in the Site Assessment and Practices Planning section for these specific areas:

Basin water quality information

Lisa McCann, Central Coast Regional Water Quality Control Board Amanda Bern, Central Coast Regional Water Quality Control Board Mark Angelo, Central Coast Regional Water Quality Control Board

Managing sediment

Giulio Ferruzzi, USDA-NRCS

Managing irrigation

Michael Cahn, UCCE Monterey County

Thomas Harter, UCCE Davis

\section{Managing pesticides}

Giulio Ferruzzi, USDA-NRCS

Jay Gan, UCCE Riverside

William Chaney, UCCE Monterey County

\section{Managing nutrients}

Giulio Ferruzzi, USDA-NRCS

Managing salinity

Michael Cahn, UCCE Monterey County

Giulio Ferruzzi, USDA-NRCS

Practices to improve water quality in waterways

Giulio Ferruzzi, USDA-NRCS

John Warner, USDA-NRCS

Richard Casale, USDA-NRCS 


\section{Self-evaluation}

Terry Hall, USDA-NRCS

\section{Commodity Information Collaborators}

The following provided technical information in the Site Assessment and Practices Planning section for these commodities:

\section{Cool-season vegetables}

Richard Smith, UCCE Monterey County

Tim Hartz, UCCE Davis

\section{Greenhouse/nursery}

Ann King, UCCE San Mateo County

John Kabashima, UCCE South Coast Research and Extension Center

Darren Haver, UCCE Orange County

Richard Evans, UCCE Davis

Aziz Baameur, UCCE Santa Clara County

Julie Newman, UCCE Ventura County

Loren Oki, UCCE Davis

Steve Tjosvold, UCCE Santa Cruz County

J. Heinrich Lieth, UCCE Davis

Orchards and vineyards

Ben Faber, UCCE Ventura

Mark Battany, UCCE San Luis Obispo County

\section{Strawberries and caneberries}

Mark Bolda, UCCE Santa Cruz County

\section{Reviewers}

Special thanks for review of Farm Water Quality Plan sections -

Mel George, UCCE Davis

Michael Isensee, UCCE San Luis Obispo County

Royce Larson, UCCE San Luis Obispo County

Margy Lindquist, USDA-NRCS

Dan Johnson, USDA-NRCS

Rebecca Challender, USDA-NRCS

Robert Fry, USDA-NRCS

Albert Cerna, USDA-NRCS

David Robledo, USDA-NRCS

Tina Vander Hoek, USDA-NRCS

Marc Los Huertos, UC Santa Cruz

Mike Hill, California Department of Fish and Game

The Farm Water Quality Working Group would like to thank the growers from

Chualar/Quail Watershed Group Pilot Course January 2001, Monterey County

Los Osos/Chorro Watershed Group Pilot Course February 2001, San Luis Obispo County Pescadero/Butano Watershed Group Pilot Course June 2001, San Mateo County

for contributions instrumental in the development of the Farm Water Quality Planning curriculum. Their participation and suggestions were invaluable in the process of building this final product.

Additionally we wish to acknowledge the efforts of Carolyn Richardson, whose energy and dedication is greatly missed. 
The Farm Water Quality Plan has been made possible with funding through:

USDA Cooperative State Research, Education, and Extension Service Water Quality Program 1999-2000

David and Lucille Packard Foundation Conserving California Landscapes Initiative 2000-2001

DANR Water Quality Workgroup Farm Water Quality Task Force 2000-2003

California State Water Resources Control Board Section 319(h) Grant Program 2001-2004

\section{FOR MORE INFORMATION}

You'll find detailed information on many aspects of resource conservation in these titles and in other publications, slide sets, CD-ROMs, and videos from UC ANR:

Farm Water Quality Planning Short Course Objectives, publication 8052

Nonpoint Sources of Pollution in Irrigated Agriculture, publication 8055

Practices for Reducing Nonpoint Source Pollution from Irrigated Agriculture, publication 8075

To order these products, visit our online catalog at http://anrcatalog.ucdavis.edu. You can also place orders by mail, phone, or fax, or request a printed catalog of publications, slide sets, CD-ROMs, and videos from

University of California

Agriculture and Natural Resources

Communication Services

6701 San Pablo Avenue, 2nd Floor

Oakland, California 94608-1239

Telephone: (800) 994-8849 or (510) 642-2431, FAX: (510) 643-5470

e-mail inquiries: danrcs@ucdavis.edu

An electronic version of this publication is available on the ANR Communication Services website at http://anrcatalog.ucdavis.edu.

\section{Publication 8332}

(C) 2009 by the Regents of the University of California, Division of Agriculture and Natural Resources. All rights reserved.

The University of California prohibits discrimination against or harassment of any person employed by or seeking employment with the University on the basis of race, color, national origin, religion, sex, physical or mental disability, medical condition (cancer-related or genetic characteristics), ancestry, marital status, age, sexual orientation, citizenship, or status as a covered veteran (special disabled veteran, Vietnam-era veteran or any other veteran who served on active duty during a war or in a campaign or expedition for which a campaign badge has been authorized).

University Policy is intended to be consistent with the provisions of applicable State and Federal laws.

Inquiries regarding the University's nondiscrimination policies may be directed to the Affirmative Action/Staff Personnel Services Director, University of California, Agriculture and Natural Resources, 300 Lakeside Drive, 6th Floor, Oakland, CA 94612-3550 (510) 987-0096.

For information about obtaining this publication, call (800) 994-8849. 